\title{
Valoración actual de las poblaciones de Acropora palmata y Acropora cervicornis en el Parque Nacional Natural Tayrona, Caribe colombiano
}

\section{Current assessment of the Acropora palmata and Acropora cervicornis populations in Tayrona National Natural Park, Colombian Caribbean}

\author{
Rocío García-Urueña*, Marco Garzón-Machado y Silvia Sierra-Escrigas \\ $\begin{array}{lll}\text { (iD) } 0000-0002-9667-3386 & \text { (iD } 0000-0002-0676-4357 & \text { (iD) } 0000-0002-8320-5727\end{array}$ \\ 1. Grupo de investigación Ecología y Diversidad de Algas Marinas y Arrecifes Coralinos, Universidad del Magdalena, Santa Marta, Colombia. \\ rgarciau@unimagdalena.edu.co*,marco.garzon@gmail.com, silore10.se@gmail.com \\ * Autora de correspondencia.
}

\section{RESUMEN}

$\mathrm{L}$ a última valoración sobre la extensión, estado y cobertura viva (\%) de las formaciones de Acropora palmata (29) y A. cervicornis (12) en el Parque Nacional Natural Tayrona fue realizada en 2001 y publicada en 2004. Estas mismas formaciones, incluyendo una adicional en isla Aguja, fueron evaluadas de nuevo entre 2016 y 2018 teniendo en cuenta las mismas variables, y adicionalmente el registro de condición de las colonias. Para A. palmata se encontraron 24 formaciones con una reducción en área de $28,9 \%$. La cobertura promedio aumentó cerca de $2,0 \%$, y se observó una amplia distribución de frecuencia de tallas y una proporción importante de colonias con territorios de peces damisela (Stegastes). El área de las formaciones de A. cervicornis se redujo 99,3 \% y solo se encontró una formación en Nenguange, aunque se registran dos nuevas y pequeñas en Cinto y otra en Chengue. La cobertura promedio fue de 8,0 \%, en su mayoría constituida por colonias de talla pequeña y principalmente afectadas por blanqueamiento, macroalgas, enfermedades y depredadores. Claramente el estatus de las dos especies es diferente por lo que requieren esfuerzos diferentes para su manejo y conservación. Las formaciones de A. palmata han persistido, pero es necesario realizar estudios continuos que permitan detectar cambios temporales, con evaluaciones de aspectos ecológicos como las afectaciones por los peces damisela. El estado de A. cerviconis es crítico, por lo que demanda acciones urgentes de restauración y otras medidas de manejo para mitigar la tendencia a su desaparición en el área.

PALABRAS CLAVE: acropóridos, formaciones coralinas, demografía poblacional

\section{ABSTRACT}

$\mathrm{T}$ The last assessment in terms of extension, status, and living coral cover (\%) of Acropora palmata (29) and A. cervicornis (12) formations in Tayrona National Natural Park was done in 2001 and published in 2004. These formations were evaluated again between 2016 and 2018, including a new formation in Aguja Island, considering the same variables, with the addition of colony condition. For A. palmata, 24 formations were found with a reduction in area of $28.9 \%$. Mean coral cover increased about $2.0 \%$, with a broad size frequency distribution and an important proportion of colonies affected by damselfish territories (Stegastes). In A. cervicornis the area was reduced in $99.3 \%$ and only one formation was found in Nenguange, although two new small formations were found in Cinto, and another one in Chengue. Mean coral cover was $8.0 \%$, composed mostly of small colonies and affected mainly by bleaching, macroalgae, diseases and predation. It is clear that the status of each species is different and requires specific conservation and management efforts. $A$. palmata formations have persisted through time, but nevertheless it is necessary to continue with similar assessments, to detect temporal changes, evaluating ecological aspects such as impacts of damselfish territories. A. cervicornis is in a critical condition and requires urgent restoration strategies and management measures to mitigate its tendency to disappear in the area.

KEY WORDS: acroporids, coral reef formations, population demography

DOI: https://doi.org/10.25268/bimc.invemar.2020.49.SuplEsp.1068

Publicado por INVEMAR

Este es un manuscrito de acceso abierto bajo la licencia CC

Reconocimiento-No Comercial-Compartir Igual 


\section{INTRODUCCIÓN}

Acropora palmata y A. cervicornis son dos especies de corales ramificados cuyas poblaciones se redujeron significativamente en todo el Caribe desde finales de la década de 1980 llevándolas a ser incluidas en la lista de especies amenazadas (Aronson et al., 2008a, 2008b). En Colombia, A. palmata se registra como En Peligro y A. cervicornis como Críticamente Amenazada (Ardila et al., 2002). El deterioro se ha atribuido a factores como enfermedades de tipo banda blanca (EBB) (Gladfelter, 1982; Aronson y Precht, 2001; Porter et al., 2001), serriatiosis de acropóridos (WPX) (Patterson et al., 2002), eventos de blanqueamiento (Hoegh-Guldberg, 1999; RodríguezRamírez et al., 2008; Navas-Camacho et al., 2010), así como a sobrepesca, desarrollo costero y cambio climático (Buddemeier et al., 2004).

En el Caribe colombiano para la década de 1990 e inicios de los años 2000 se registró igualmente la reducción de las poblaciones de $A$. palmata y A. cervicornis (Díaz et al., 1995, 2000; Garzón-Ferreira, 1997; López-Victoria y Díaz, 2000; Cendales et al., 2002), con mortalidades en el Parque Nacional Natural Tayrona (PNNT) de hasta $60 \%$ para $A$. palmata y $80 \%$ para $A$. cervicornis (Garzón-Ferreira y Cano, 1991). Garzón-Ferreira et al. (2004) valoraron en 2001 estas dos especies en el PNNT con referencia a la ubicación, extensión, composición y cobertura de la comunidad coralina y otros organismos sésiles. Para A. palmata se estudiaron 29 formaciones que tuvieron una cobertura promedio de $10 \%$, una extensión de $14000 \mathrm{~m}^{2}$ de tejido vivo, mientras que de 12 formaciones de $A$. cervicornis solo cuatro exhibieron colonias vivas con una cobertura promedio de $5 \%$ para un área viva de solo $1200 \mathrm{~m}^{2}$. En general, al interior de las formaciones de estos corales las algas presentaron una cobertura de $80 \%$, seguidas por los corales pétreos. Los resultados indicaron que las poblaciones de estas dos especies aún no mostraban signos de recuperación.

En el Caribe en la última década se han realizado valoraciones tendientes a establecer los cambios en las poblaciones de los acropóridos, principalmente para tener evidencia de si estas han mostrado signos de recuperación o, por el contrario, su deterioro ha seguido en aumento. Estos trabajos incluyen 1) la construcción de mapas de hábitats potenciales de las dos especies para la Florida, Puerto Rico e islas Vírgenes (Wirt et al., 2013, 2015), y 2) la evaluación del estado de las poblaciones de $A$. palmata a lo largo de los arrecifes mesoamericanos (México,

\section{INTRODUCTION}

Acropora palmata and A. cervicornis are two species of branched coral whose populations have declined significantly throughout the Caribbean since the late 1980s, leading them to be included in the list of threatened species (Aronson et al., 2008a, 2008b). In Colombia, A. palmata is recorded as Endangered, and A. cervicornis as Critically Endangered (Ardila et al., 2002). The deterioration has been attributed to factors such as white band diseases (EBB) (Gladfelter, 1982; Aronson and Precht, 2001; Porter et al. 2001), Acropora serriatiosis (WPX) (Patterson et al., 2002), events of bleaching (Hoegh-Guldberg, 1999; Rodríguez-Ramírez et al. 2008; Navas-Camacho et al. 2010), as well as overfishing, coastal development and climate change (Buddemeier et al., 2004).

In the Colombian Caribbean, for the 1990s and early 2000s, the reduction of the populations of $A$. palmata and $A$. cervicornis was also recorded (Díaz et al., 1995, 2000; Garzón-Ferreira, 1997; López-Victoria and Díaz, 2000; Cendales et al., 2002), with mortalities in the Tayrona National Natural Park (TNNP) of up to $60 \%$ for A. palmata and $80 \%$ for A. cervicornis (Garzón-Ferreira and Cano, 1991). Garzón-Ferreira et al. (2004) evaluated these two species in 2001 in the TNNP regarding the location, extension, composition, and coverage of the coral community and other sessile organisms. For A. palmata, 29 formations were studied that had average coverage of $10 \%$, an area of $14000 \mathrm{~m}^{2}$ of living tissue, while of 12 formations of $A$. cervicornis only four exhibited live colonies with an average coverage of $5 \%$ for a living area of only $1200 \mathrm{~m}^{2}$. In general, within the formations of these corals, the algae presented coverage of $80 \%$, followed by the stony corals. The results indicated that the populations of these two species still did not show signs of recovery.

In the Caribbean, in the last decade, assessments have been carried out to establish changes in the populations of the acroporids, mainly to have evidence of whether they have shown signs of recovery or, on the contrary, their deterioration has continued to increase. These works include 1) the construction of maps of potential habitats of the two species for Florida, Puerto Rico, and the Virgin Islands (Wirt et al., 2013, 2015), and 2) the evaluation of the state of the $A$. palmata populations along the Mesoamerican reefs (Mexico, Belize, Guatemala, and Honduras), of the 107 reefs studied, only 15 showed recovery and only in one an increase in coverage was observed. (RodríguezMartínez et al., 2014). In the reef system of Veracruz in the 
Belice, Guatemala y Honduras), donde de 107 arrecifes estudiados, solo 15 presentaron recuperación y solo en uno se observó aumento de cobertura (Rodríguez-Martínez et al., 2014). En el sistema arrecifal de Veracruz en el golfo de México, Larson et al. (2014) sugirieron recuperación de A. palmata al encontrar colonias sanas, abundantes y con una amplia distribución y mayor densidad comparada con otras regiones del Caribe. En Jamaica, luego del evento de blanqueamiento de 2005, las poblaciones de $A$. palmata evidenciaron una recuperación de $2 \%$ a $22 \%$ en 2008 (Crabbe, 2009). En islas Vírgenes entre 2003-2010, Rogers y Muller (2012) encontraron que la enfermedad de serriatosis de acropóridos sigue siendo una de las principales causas de deterioro en A. palmata. En Los Roques, Venezuela, Croquer et al. (2016) documentaron cómo se ha perdido $50 \%$ de la distribución original de A. palmata por blanqueamientos masivos, mientras que en los arrecifes de Cuba Caballero-Aragón et al. (2020) concluyeron que $A$. palmata presentaba un estatus de regular a malo en cerca de $90 \%$ de los arrecifes.

En cuanto a estudios poblacionales, al ser los acropóridos especies ramificadas y de rápido crecimiento, son susceptibles al rompimiento y fragmentación (Hughes y Connell, 1999), aunque esta es una forma de reproducción y dispersión asexual que permite una rápida colonización del sustrato (Hughes et al., 1992; Hall y Hughes, 1996). La dificultad radica en determinar tasas demográficas, que están basadas en el crecimiento, mortalidad y fecundidad, factores que dependen del tamaño de las colonias (Hughes y Jackson, 1985; Soong, 1993), y no es sencillo distinguir si las colonias pequeñas provienen de mortalidad parcial, son nuevos reclutas o se han fragmentado. Por ello, variables como el sesgo y la curtosis son usados como indicadores de la preponderancia en la distribución de tallas pequeñas o grandes, así como la transformación logarítmica que se usa para visualizar más finamente las clases de tallas pequeñas y combina menos clases de talla (Meesters et al., 2001). De acuerdo con Bak y Meesters (1998), la demografía puede cambiar con los gradientes y condiciones ambientales, lo cual se refleja en las distribuciones de talla contrastantes entre distintas poblaciones; por esto, conocer el régimen de perturbaciones puede ayudar a inferir procesos demográficos. De ahí que estudios de la estructura de tallas de las poblaciones permiten examinar diferencias espaciales, temporales o taxonómicas en la historia de vida, evaluar respuestas a perturbaciones como blanqueamiento o evaluar la estructura de edades (Adjeroud et al., 2007; Crabbe, 2009; Anderson y Pratchett, 2014).
Gulf of Mexico, Larson et al. (2014) suggested recovery of A. palmata by finding healthy, abundant colonies with a wide distribution and greater density compared to other regions of the Caribbean. In Jamaica, after the bleaching event of 2005, A. palmata populations showed a recovery of $2 \%$ to $22 \%$ in 2008 (Crabbe, 2009). In the Virgin Islands between 2003-2010, Rogers and Muller (2012) found that acroporid serriatosis disease continues to be one of the main causes of deterioration in A. palmata. In Los Roques, Venezuela, Croquer et al. (2016) documented how $50 \%$ of the original distribution of $A$. palmata has been lost due to massive bleaching, while in the reefs of Cuba CaballeroAragón et al. (2020) concluded that A. palmata had a fair to poor status in about $90 \%$ of the reefs.

Regarding population studies, as the acroporids are branched and fast-growing species, they are susceptible to breaking and fragmentation (Hughes and Connell, 1999), although this is a form of asexual reproduction and dispersal that allows rapid colonization of the substrate (Hughes et al., 1992; Hall and Hughes, 1996). The difficulty lies in determining demographic rates, which are based on growth, mortality, and fertility, factors depending on the size of the colonies (Hughes and Jackson, 1985; Soong, 1993), and it is not easy to distinguish if the small colonies came from partial mortality, recruit or have become fragmented. Therefore, variables such as bias and kurtosis are used as indicators of the preponderance in the distribution of small or large sizes, as well as the logarithmic transformation that is used to visualize the small size classes more finely and combine fewer size classes (Meesters et al., 2001). According to Bak and Meesters (1998), demographics can change with gradients and environmental conditions, which is reflected in the contrasting size distributions between different populations; For this reason, knowing the disturbance regime can help infer demographic processes. Hence, studies of the size structure of populations allow examining spatial, temporal, or taxonomic differences in life history, evaluating responses to disturbances such as bleaching, or evaluating age structure (Adjeroud et al., 2007; Crabbe, 2009; Anderson and Pratchett, 2014).

In Colombia, only one assessment of the status of the populations of the two Acropora species has been carried out: this was done 15 years after the loss of coverage began (Garzón-Ferreira et al., 2004). Taking into account the above, the present study, almost 20 years after the said assessment, presents information on the current state, 
En Colombia se ha realizado solo una evaluación del estado de las poblaciones de las dos especies de Acropora: esta se hizo luego de 15 años de iniciarse la pérdida de cobertura (Garzón-Ferreira et al., 2004). Teniendo en cuenta lo anterior, el presente estudio, casi 20 años después de dicha valoración, presenta información sobre el estado actual, cobertura, condición, áreas de las formaciones e incluye, además, aspectos de la demografía como la estructura de tallas. Estos datos son una línea de base que puede aportar a futuros estudios que permitan estimar posibles cambios espaciales y temporales de las poblaciones de acropóridos en el PNNT.

\section{ÁREA DE ESTUDIO}

El estudio se realizó en el PNNT localizado en la costa norte de Colombia entre los $11^{\circ} 17^{\prime}-11^{\circ} 22^{\prime} \mathrm{N}$ y $73^{\circ} 53^{\prime}$ $74^{\circ} 12^{\prime} \mathrm{W}$. Este incluye un número de bahías con arrecifes de coral, pastos marinos, bosques de manglar y playas arenosas (Garzón-Ferreira y Díaz, 2003). Información detallada sobre las condiciones climáticas y oceanográficas del área se encuentrean en varias publicaciones (Andrade et al., 2003, Bayraktarov et al., 2014a, 2014b). Se evaluaron las formaciones de Acropora en las bahías de Chengue, Gayranca, Nenguange y Cinto, y se incluyó la formación de A. palmata ubicada en El Torín en isla Aguja, que, aunque no fue evaluada previamente, hace parte del PNNT (Figura 1).

\section{MATERIALES Y MÉTODOS}

Estimación de las áreas de cada formación

Se realizó un mapa de referencia con las formaciones coralinas de $A$. palmata (FAP) y A. cervicornis (FAC) registradas para las bahías de Cinto, Nenguange, Gayraca y Chengue en el PNNT por Garzón-Ferreira et al. (2004). Los muestreos se realizaron entre octubre de 2016 y mayo de 2018 y para evaluar el área de las poblaciones de las dos especies se visitaron las mismas bahías y se verificó la ubicación geográfica de cada formación. Las formaciones se delimitaron con boyas que luego fueron georeferenciadas usando un GPS Garmin eTrex 20 de 3 m de precisión. En los parches pequeños se tomaron medidas directas del área con cintas métricas. Adicionalmente, fueron configuradas misiones con un dron Phantom 4 para registrar las formaciones más someras.

Con los puntos GPS de los límites de cada parche, se calcularon los polígonos que representaron el coverage, condition, areas of the formations and also includes aspects of demography such as the size structure. These data are a baseline that can contribute to future studies that made it possible to estimate possible spatial and temporal changes of the populations of acroporids in the TNNP.

\section{STUDY AREA}

The study was conducted at the TNNP located on the north coast of Colombia between $11^{\circ} 17^{\prime}-11^{\circ} 22^{\prime}$ $\mathrm{N}$ and $73^{\circ} 53^{\prime}-74^{\circ} 12^{\prime} \mathrm{W}$. This includes several bays with coral reefs, pastures marine, mangrove forests, and sandy beaches (Garzón-Ferreira and Díaz, 2003). Detailed information on the climatic and oceanographic conditions of the area can be found in various publications (Andrade et al. 2003; Bayraktarov et al., 2014a, 2014b). The Acropora formations in the bays of Chengue, Gayranca, Nenguange, and Cinto were evaluated, and the formation of A. palmata located in El Torín on Aguja Island was included, which, although not previously evaluated, is part of the TNNP (Figure 1).

\section{MATERIALS AND METHODS}

\section{Estimation of the areas of each formation}

A reference map was made with the coral formations of $A$. palmata (FAP) and A. cervicornis (FAC) registered for the bays of Cinto, Nenguange, Gayraca, and Chengue in the TNNP by Garzón-Ferreira et al. (2004). The samplings were carried out between October 2016 and May 2018 and to evaluate the area of the populations of the two species, the same bays were visited and the geographical location of each formation was verified. The formations were delineated with buoys that were then georeferenced using a $3 \mathrm{~m}$ precision Garmin eTrex 20 GPS. In the small patches, direct measurements of the area were taken with tape measures. Additionally, missions were set up with a Phantom 4 drone to record the shallowest formations.

With the GPS points of the boundaries of each patch, the polygons that represented the estimated area of each formation were calculated; For this, the ArcGIS 10.4 geographic information system (GIS) was used. In the formations where visibility conditions are allowed, aerial images were used for the construction of orthophotomosaics using the Pix4D professional mapping program, with which the areas were calculated with greater precision. 


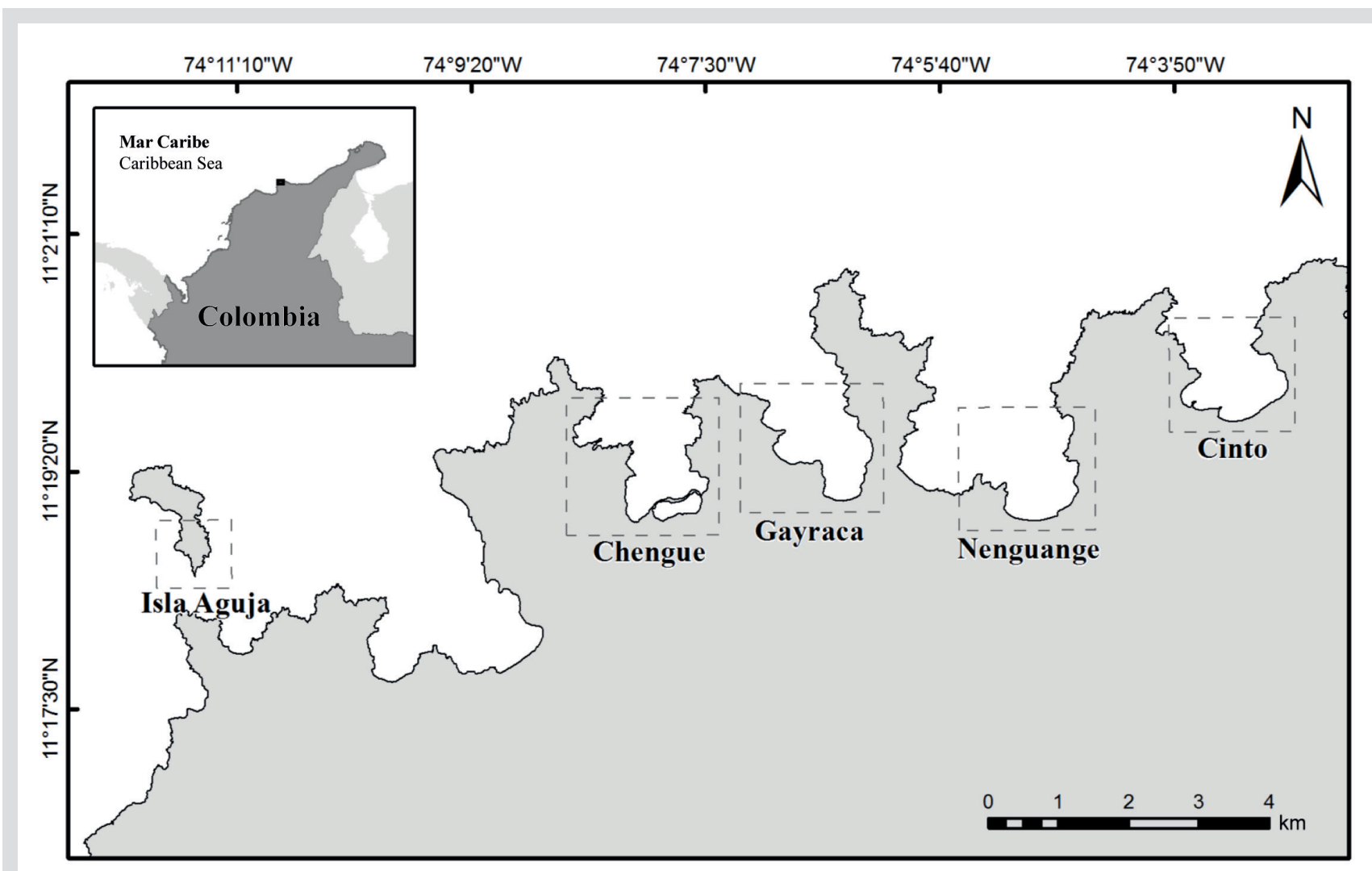

Figura 1. Localización de bahías e isla Aguja en el PNNT, donde se encuentran las formaciones de Acropora.
Figure 1. Location of bays and Aguja Island in the TNNP where the Acropora formations are found. área estimada de cada formación; para ello se utilizó el sistema de información geográfica (SIG) ArcGIS 10.4. En las formaciones donde las condiciones de visibilidad lo permitieron, se utilizaron las imágenes aéreas para la construcción de ortofotomosaicos mediante el programa de mapeo profesional Pix4D, con los cuales se calcularon las áreas con una mayor precisión.

\section{Estructura poblacional, cobertura y condición}

En cada formación donde se encontraron colonias vivas se realizó la valoración de su cobertura, tallas y condición. Dependiendo del tamaño de cada formación, se dispusieron entre uno y cinco transectos lineales de $10 \mathrm{~m}$ (entre 2 y $10 \mathrm{~m}$ de profundidad) y se realizaron videos a lo largo del transecto. Para el cálculo de cobertura del sustrato, el registro de video fue analizado utilizando el programa Coral Point Count. Inicialmente, 20 imágenes fueron capturadas a intervalos de $5 \mathrm{~s}$, y a cada una aleatoriamente se le asignaron 50 puntos. Con base en ellos se estimó la cobertura de los componentes del sustrato (Kohler y Gill, 2006). Para evaluar si existían diferencias en cobertura de los componentes de A. palmata, macroalgas y otras
Population structure, coverage, and condition

In each formation where living colonies were found, an assessment of their coverage, sizes, and condition was carried out. Depending on the size of each formation, between one and five $10 \mathrm{~m}$ linear transects (between 2 and $10 \mathrm{~m}$ deep) were arranged, and videos were made along the transect. To calculate the coverage of the substrate, the video record was analyzed using the Coral Point Count program. Initially, 20 images were captured at $5 \mathrm{~s}$ intervals, and each one was randomly assigned 50 points. Based on them, the coverage of the substrate components was estimated (Kohler and Gill, 2006). To assess whether there were differences in coverage of the components of A. palmata, macroalgae, and other coral species (except Acropora) between this study and that of Garzón-Ferreira et al. (2004) the Wilcoxon test of ranges was used for related samples, as the data did not meet the assumption of normality for the cover of A. palmata and macroalgae, while for the cover of other corals the paired t-Student test with the data transformed to arcsine, after fulfilling the normality assumption (Shapiro-Wilks). For A. cervicornis 
especies de coral (exceptuando Acropora) entre este estudio y el de Garzón-Ferreira et al. (2004) se utilizó la prueba de Wilcoxon de rangos para muestras relacionadas, al no cumplir los datos el supuesto de normalidad para la cobertura de A. palmata y las macroalgas. Mientras tanto, para la cobertura de otros corales se usó la prueba pareada de t-Student con los datos transformados a arcoseno, previo cumplimiento del supuesto de normalidad (Shapiro-Wilks). Para A. cervicornis no fue posible realizar comparaciones al no encontrarse sino una sola FAC de las previamente registradas.

A lo largo de cada formación se midió el diámetro mayor (L) y el diámetro perpendicular al diámetro mayor (1) del mayor número de colonias individuales. El área de cada colonia fue calculada aproximando a una elipse $(\mathrm{A}=(\mathrm{L} / 2 \times 1 / 2) \times \pi$; Yap et al., 1992; Linares et al., 2011). La diferencia en la talla de las colonias $\left(\mathrm{cm}^{2}\right)$ entre bahías se comparó a través de la prueba de Kruskal-Wallis al no cumplir el supuesto de normalidad (Shapiro-Wilk $\mathrm{P}<0,05$ ) y se realizó la prueba post-hoc de Dunn. La estructura de tallas para cada bahía se examinó a través de una tabla de distribución de frecuencias, con la cual se calculó el tamaño promedio, la desviación estándar y el coeficiente de variación $(\mathrm{CV})$. El sesgo $\left(\mathrm{g}_{1}\right)$ fue usado para describir la proporción de colonias que son más pequeñas o grandes que la media y la curtosis $\left(\mathrm{g}_{2}\right)$ para describir si las distribuciones de frecuencia tienen picos más pronunciados o más planos que una distribución normal (Anderson y Pratchett, 2014). Luego, los datos fueron transformados a logaritmo $\left(\log _{10}\right)$ para obtener una distribución normal e incrementar la resolución de tallas pequeñas (Bak y Meesters, 1998; Vermeij y Bak, 2003). Para comprobar si las distribuciones provenían de una distribución normal, se utilizó la prueba de Kolmogorov-Smirnov con la corrección de Lilliefors.

Para evaluar la condición en términos de salud en cada formación se realizó un registro videofotográfico sobre cada colonia. Para A. palmata se registraron colonias sanas, presencia de enfermedades (WPX o EBB), territorios de damiselas, evidenciados como lesiones sobre el tejido vivo, y presencia de signos de depredación de gusanos de fuego y caracoles. Para A. cervicornis se registraron colonias sanas, $\mathrm{EBB}$, competencia con macroalgas, territorios de damiselas, signos de depredación de gusano de fuego y caracoles, y blanqueamiento. Con el total de colonias muestreadas se calculó la incidencia (\%) de cada tipo de condición en cada una de las formaciones. it was not possible to make comparisons as there was only one FAC of those previously recorded.

During each training, the largest diameter (L) and the diameter perpendicular to the largest diameter (1) of the highest number of single colonies was measured. The area of each colony was calculated by approximating an ellipse $(A=(L / 2 \times 1 / 2) \times \pi$; Yap et al., 1992; Linares et al., 2011). The difference in the size of the colonies $\left(\mathrm{cm}^{2}\right)$ between bays was compared by the Kruskal-Wallis failure to meet the assumption of normality (Shapiro-Wilk $\mathrm{P}<0.05$ ) and the post-hoc Dunn test was performed. The size structure for each bay was examined through a frequency distribution table, with which the average size was used to calculate standard deviation and coefficient of variation (CV). Bias $\left(g_{1}\right)$ was used to describe the proportion of colonies that are smaller or larger than average and kurtosis $\left(\mathrm{g}_{2}\right)$ to describe whether the frequency distributions are flatter peaks, more pronounced, or normal distribution (Anderson and Pratchett, 2014). Then the data were transformed to the logarithm $\left(\log _{10}\right)$ for normal distribution and the resolution of small sizes increased (Meesters and Bak 1998; Vermeij and Bak 2003). To check whether the distributions came from a normal distribution, the Kolmogorov-Smirnov test was used with correction Lilliefors.

To evaluate the condition in terms of health in each formation, a video-photographic record was made on each colony. For A. palmata, healthy colonies, presence of diseases (WPX or EBB), damsel territories, evidenced as lesions on living tissue, and the presence of signs of predation by fireworms and snails were recorded. For A. cervicornis, healthy colonies, EBB, competition with macroalgae, damsel territories, signs of fireworm and snail predation, and bleaching were recorded. With the total number of colonies sampled, the incidence (\%) of each type of condition in each of the formations was calculated. 


\section{RESULTADOS}

\section{Distribución y áreas}

Se evaluó un total de 30 formaciones que cubrieron un área de $93157 \mathrm{~m}^{2}$. De las 29 FAP descritas por GarzónFerreira et al. (2004) se encontraron 23 con un área de $84825 \mathrm{~m}^{2}$ y de las 4 FAC solo se encontró una en Nenguange con $158 \mathrm{~m}^{2}$. Se incluyen dos formaciones adicionales de $A$. palmata en el PNNT, una en Nenguange de $6020 \mathrm{~m}^{2}$ y una en Chengue de $1996 \mathrm{~m}^{2}$, en adición a la formación de A. palmata en isla Aguja en el sector El Torín con un área de $315 \mathrm{~m}^{2}$. Para A. cervicornis se distinguieron colonias completas y se incluyen dos formaciones pequeñas en la bahía de Cinto con 24,0 y $81,0 \mathrm{~m}^{2}$ y en Chengue se georeferenció la presencia de la especie al interior de la bahía, pero eran pequeñas colonias aisladas que no constituyen una formación. El área, localización y código de identificación de cada formación aparece en Material suplementario 1.

Teniendo en cuenta únicamente la comparación del área para las formaciones previamente detectadas y aún existentes, los datos en general muestran una reducción de las FAP en las bahías del PNNT de $34494 \mathrm{~m}^{2}$ (28,9 \%). Sin embargo, se obtuvo un aumento en área para nueve formaciones equivalente a $5480 \mathrm{~m}^{2}$, mientras la reducción se dio en 14 formaciones $\left(28031 \mathrm{~m}^{2}\right)$. Las formaciones $4 \mathrm{P}$ en Chengue y 25P en Cinto siguen siendo las de mayor área en todo el PNNT. Sin embargo, hubo una reducción importante de 40,7 \% en Cinto, mientras solo de 3,6 \% en Chengue. Para las FAC la reducción en área en general fue de 99,3\%, y solamente la formación de Nenguange 7C presentó colonias vivas, y pasó de $924 \mathrm{~m}^{2}$ a $158 \mathrm{~m}^{2}$ (reducción de $83 \%$ ).

En la formación del sector de El Torín, al sureste de isla Aguja, es posible encontrar colonias dispersas de $A$. palmata entre 5 y $8 \mathrm{~m}$ de profundidad. Estas continúan hasta llegar a la parte somera, muy expuesta al embate de las olas a $1 \mathrm{~m}$ de profundidad (Figura 2). En la bahía de Chengue, no se encontró la formación $2 \mathrm{P}$, pero se registró una formación adicional en el sector protegido (3PN) a $2 \mathrm{~m}$ de profundidad, que comparte sectores con parches importantes de Millepora spp., Madracis decactis y colonias masivas como Orbicella faveolata y Pseudodiploria strigosa (Figura 3). En Gayraca no se encontró la formación 10P del lado expuesto de la bahía y la 11P del lado protegido (Figura 4). En Nenguange aún se encuentra el mayor número de formaciones $(\mathrm{n}=10)$ de las registradas por Garzón-Ferreira et al. (2004). En esta bahía no fue posible ubicar la formación 22P, aunque

\section{RESULTS}

\section{Distribution and areas}

A total of 30 formations were evaluated, covering an area of $93157 \mathrm{~m}^{2}$. Of the 29 FAPs described by GarzónFerreira et al. (2004), 23 were found with an area of 84825 $\mathrm{m}^{2}$ and of the 4 FACs only one was found in Nenguange with $158 \mathrm{~m}^{2}$. Two additional $A$. palmata formations are included in the NTP; one in Nenguange with $6020 \mathrm{~m}^{2}$ and one in Chengue with $1996 \mathrm{~m}^{2}$, in addition to the $A$. palmata formation in Aguja Island in the El Torín sector with an area of $315 \mathrm{~m}^{2}$. A. cervicornis complete colonies were distinguished and two small formations are included in Cinto Bay with 24.0 and $81.0 \mathrm{~m}^{2}$ and in Chengue the presence of the species was georeferenced inside the bay, but they were small isolated colonies that do not constitute a formation. The area, location, and identification code of each training appear in Supplementary Material 1.

Taking into account only the comparison of the area for previously detected and still existing formations, the data, in general, show a reduction of the PAF in the bays of the TNNP of $34494 \mathrm{~m}^{2}$ (28.9\%). However, an increase in area was obtained for nine formations equivalent to $5480 \mathrm{~m}^{2}$, while the reduction occurred in 14 formations $\left(28031 \mathrm{~m}^{2}\right)$. Formations $4 \mathrm{P}$ in Chengue and 25P in Cinto continue to be the largest in the entire TNNP area. However, there was a significant reduction of $40.7 \%$ in Cinto, while only $3.6 \%$ in Chengue. For the FACs, the reduction in the general area was $99.3 \%$, and only the Nenguange 7C formation presented live colonies and went from $924 \mathrm{~m}^{2}$ to $158 \mathrm{~m}^{2}$ ( $83 \%$ reduction).

In the formation of the El Torín sector, southeast of Aguja Island, it is possible to find scattered colonies of A. palmata between 5 and $8 \mathrm{~m}$ deep. These continue until they reach the shallow part, very exposed to the impact of the waves at a depth of $1 \mathrm{~m}$ (Figure 2). In Chengue Bay, the $2 \mathrm{P}$ formation was not found, but an additional formation was recorded in the protected sector (3PN) at $2 \mathrm{~m}$ depth, which shares sectors with important patches of Millepora spp., Madracis decactis, and massive colonies such as Orbicella faveolata and Pseudodiploria strigosa (Figure 3). Formation 10P on the exposed side of the bay and 11P on the protected side were not found at Gayraca (Figure 4). In Nenguange there is still the highest number of formations $(n=10)$ of those registered by Garzón-Ferreira et al. (2004). In this bay it was not possible to locate the 22P formation, although the protected side formation 


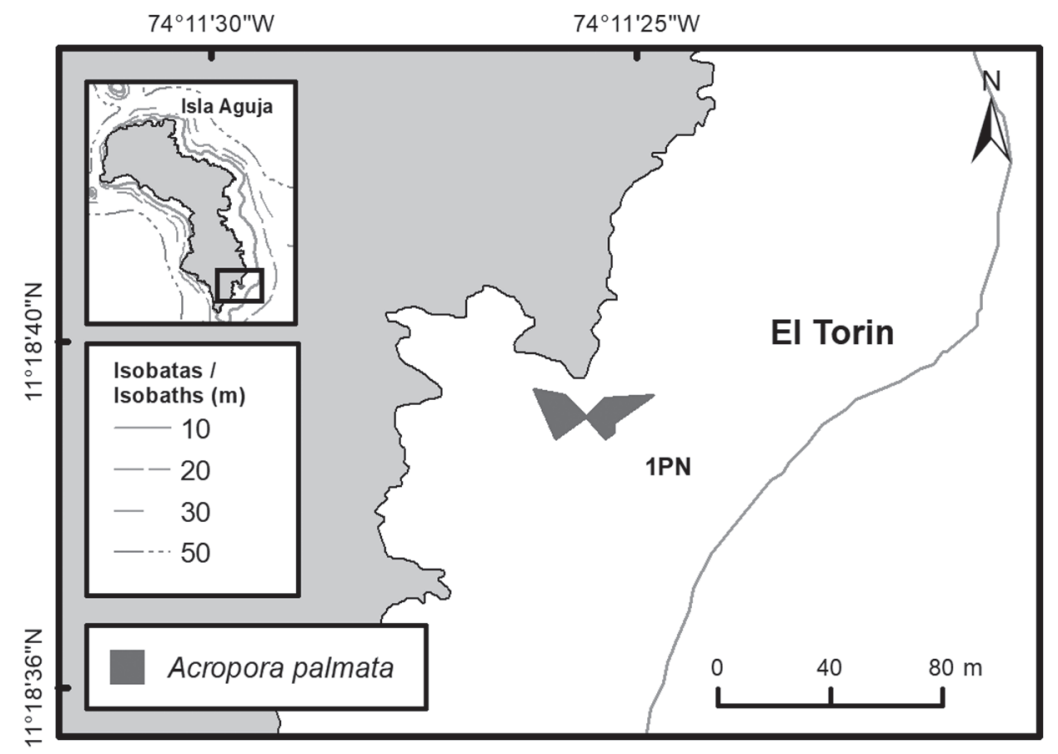

Figura 2. Ubicación de la formación de Acropora palmata en isla Aguja, 2018.

Figure 2. Location of the Acropora palmata formation on Aguja Island, 2018.

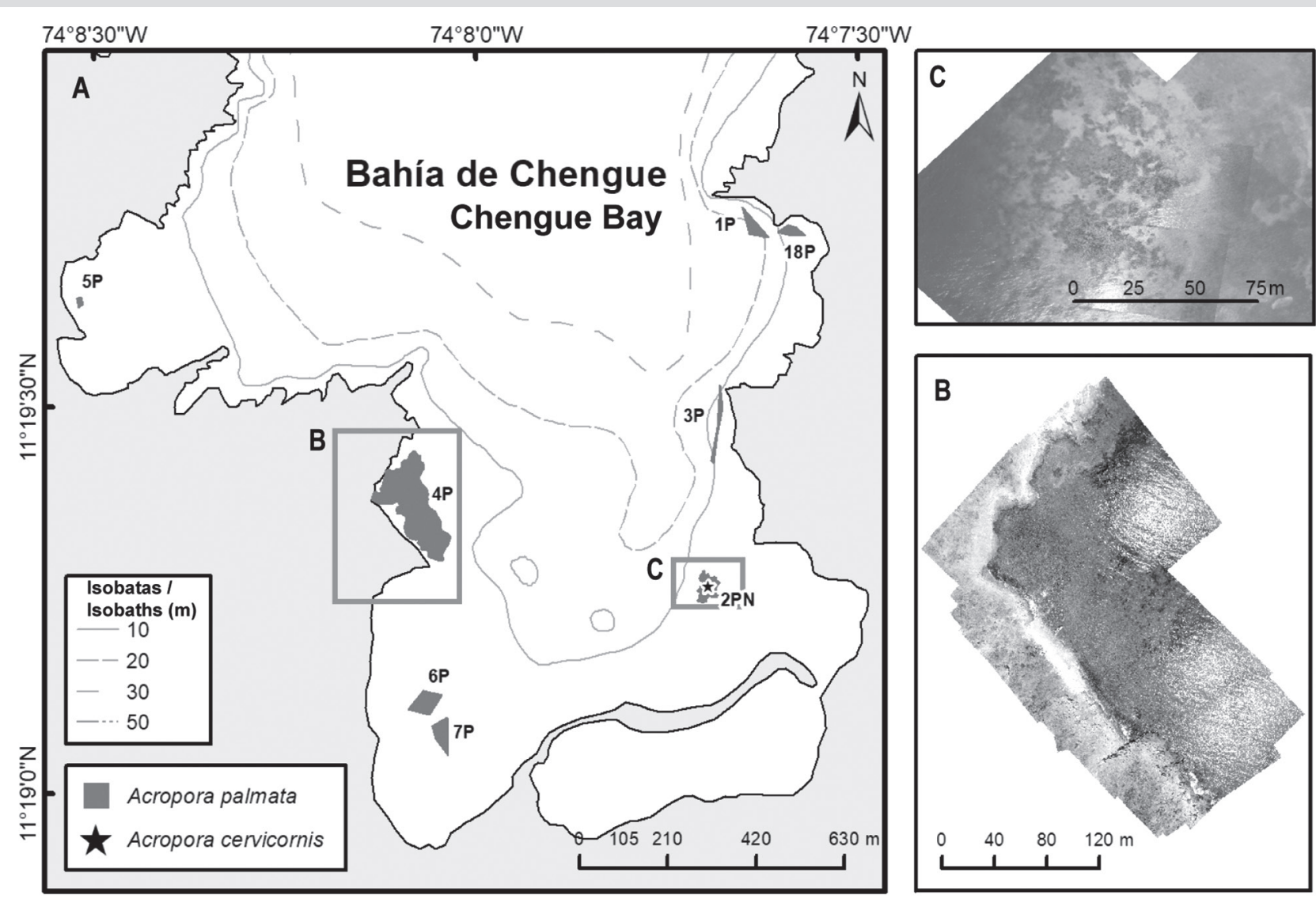

Figura 3. A) Ubicación de las formaciones de Acropora palmata y colonias aisladas de $A$. cervicornis en la bahía de Chengue, 2016-2018. B) Mosaico de fotografías aéreas para delimitar 2PN (parche nuevo de $A$ palmata). C) Mosaico de fotografías aéreas para delimitar 4P.
Figure 3. A) Location of Acropora palmata formations and isolated colonies of A. cervicornis in Chengue Bay, 2016-2018. B) Mosaic of aerial photographs to delimit 2PN (new patch of $A$ palmata). C) Mosaic of aerial photographs to delimit $4 \mathrm{P}$. 

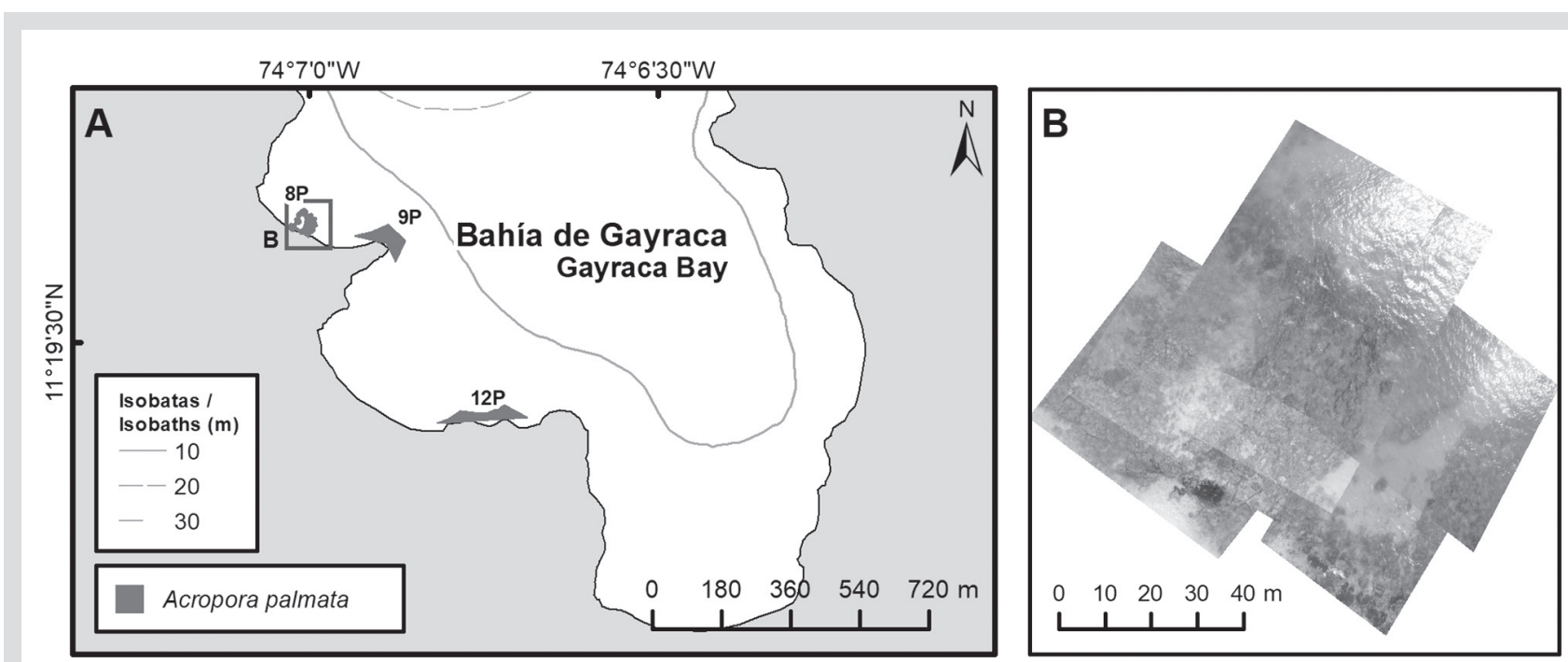

Figura 4. A) Ubicación de las formaciones de Acropora palmata en la bahía de Gayraca, 2016-2018. B) Mosaico de fotografías aéreas para delimitar $8 \mathrm{P}$.
Figure 4. A) Location of Acropora palmata formations in Gayraca Bay, 2016-2018. B) Mosaic of aerial photographs to delimit 8P. se incluye la formación del lado protegido, la cual fue denominada 3PN, al considerar que podría hacer parte de la formación 20P previamente descrita, pero que de acuerdo con el método utilizado pudo quedar fuera de la evaluada en 2001 (Figura 5). En Cinto igualmente no se encontraron dos formaciones del lado protegido (28P y 29P) y, aunque se ha reducido la formación 25P, esta sigue cubriendo un área importante (Figura 6).

En cuanto a las FAC solo la formación 7C fue encontrada en la bahía de Nenguange (Figura 5). Se incluye el registro realizado en 2009 de la formación en buen estado de salud, en 2010 con registro de blanqueamiento y en 2011 ya se observaba su deterioro (Figura 7).

\section{Cobertura de Acropora palmata}

La cobertura promedio ( \pm desviación estándar) de A. palmata en el PNNT fue de 19,9 $\pm 9,2 \%$; de macroalgas $52,0 \pm 11,1 \%$ y de corales en general $19,1 \pm 11,6 \%$. La menor cobertura se encontró en la formación 6P de Chengue con tan solo 1,8\% y la mayor en Gayraca $8 \mathrm{P}$ con $42,3 \%$ (Figura 8 ). De las $23 \mathrm{FAP}$ en que se logró comparar la cobertura de $A$. palmata con respecto a la valoración del 2001, solo en cinco no se observó aumento en cobertura, resaltándose la mayor pérdida en $6 \mathrm{P}(64,0 \%), 4 \mathrm{P}(50 \%)$ y $5 \mathrm{P}(50,0 \%)$ en la bahía de Chengue. El análisis de las 23 FAP comparadas mostró un aumento significativo en cobertura promedio (Prueba de Wilcoxon $\mathrm{T}_{23}=2,49 ; \mathrm{P}=0,012$ ) de $11 \%$ en Garzón-Ferreira et al. (2004) a 19,9\% en este estudio. Las macroalgas is included, which it was called 3PN, considering that it could be part of the previously described 20P formation, but that according to the method used could be left out of the evaluation in 2001 (Figure 5). At Cinto, no two formations were found on the protected side (28P and 29P) and, although the 25P formation has been reduced, it still covers an important area (Figure 6).

As for the FACs, only the $7 \mathrm{C}$ formation was found in Nenguange Bay (Figure 5). The registry made in 2009 of training in good health is included, in 2010 with a whitening registry and in 2011 its deterioration was already observed (Figure 7).

\section{Acropora palmata cover}

The average coverage ( \pm standard deviation) of $A$. palmata in the TNNP was $19.9 \pm 9.2 \%$; macroalgae 52.0 $\pm 11.1 \%$ and corals in general $19.1 \pm 11.6 \%$. The lowest coverage was found in the Chengue 6P formation with only $1.8 \%$ and the highest in Gayraca 8P with $42.3 \%$ (Figure 8). Of the 23 FAP in which it was possible to compare the $A$. palmata coverage with respect to the 2001 valuation, only in five was no increase in coverage observed, highlighting the greatest loss in $6 \mathrm{P}(64.0 \%), 4 \mathrm{P}(50 \%)$, and $5 \mathrm{P}(50.0 \%)$ in Chengue Bay. The analysis of the 23 FAPs compared showed a significant increase in average coverage (Wilcoxon test $\mathrm{T}_{23}=2.49 ; \mathrm{P}=0.012$ ) of $11 \%$ in GarzónFerreira et al. (2004) to $19.9 \%$ in this study. Macroalgae showed a significant decrease in all PAFs except for $8 \mathrm{P}$ 

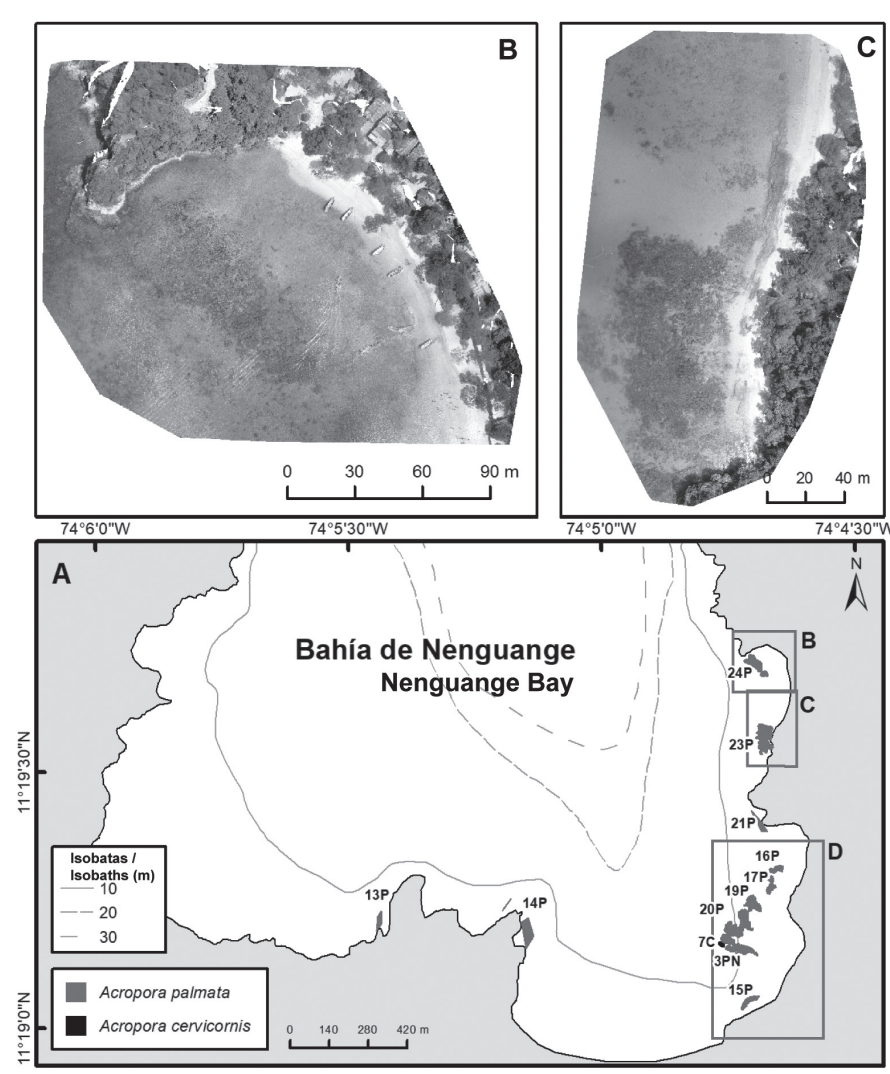

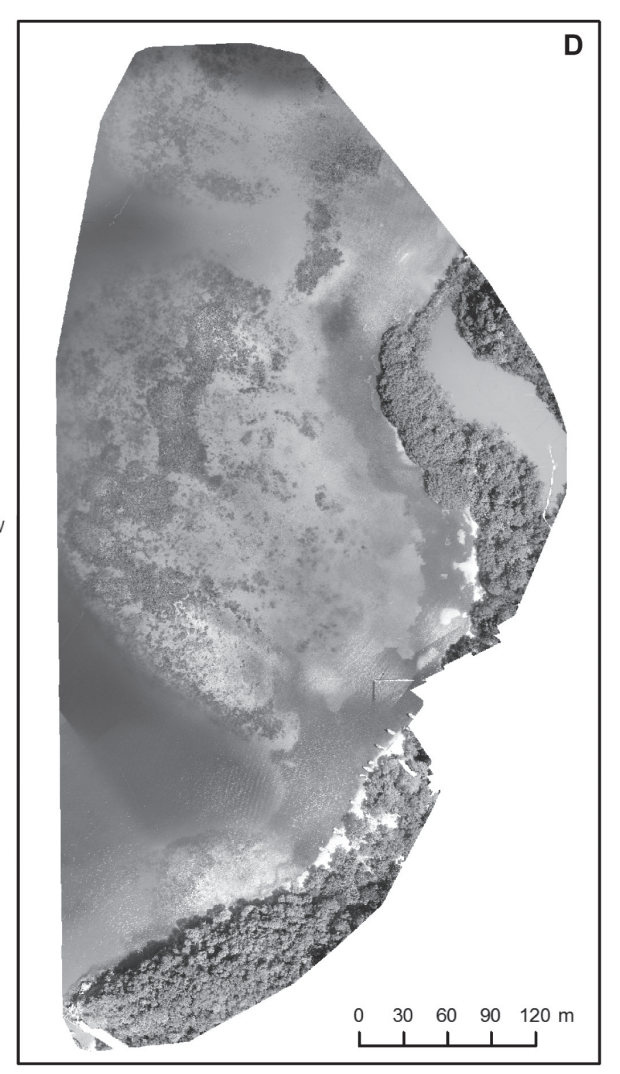

Figure 5. A) Location of the Acropora palmata and A. cervicornis formations in Nenguange Bay, 2016-2018. B) Mosaic of aerial frames to anchor 24P. C) Mosaic of aerial frames to anchor 23P. D) Mosaic of frames to anchor polygons 16P, 17P, 20P, 3PN and 15P.
Figura 5. A) Ubicación de las formaciones de Acropora palmata y A. cervicornis en la bahía de Nenguange, 2016-2018. B) Mosaico de fotogramas aéreas para delimitar 24P. C) Mosaico de fotogramas aéreas para delimitar 23P. D) Mosaico de fotogramas para delimitar los polígonos $16 \mathrm{P}, 17 \mathrm{P}, 20 \mathrm{P}, 3 \mathrm{PN}$ y $15 \mathrm{P}$. 


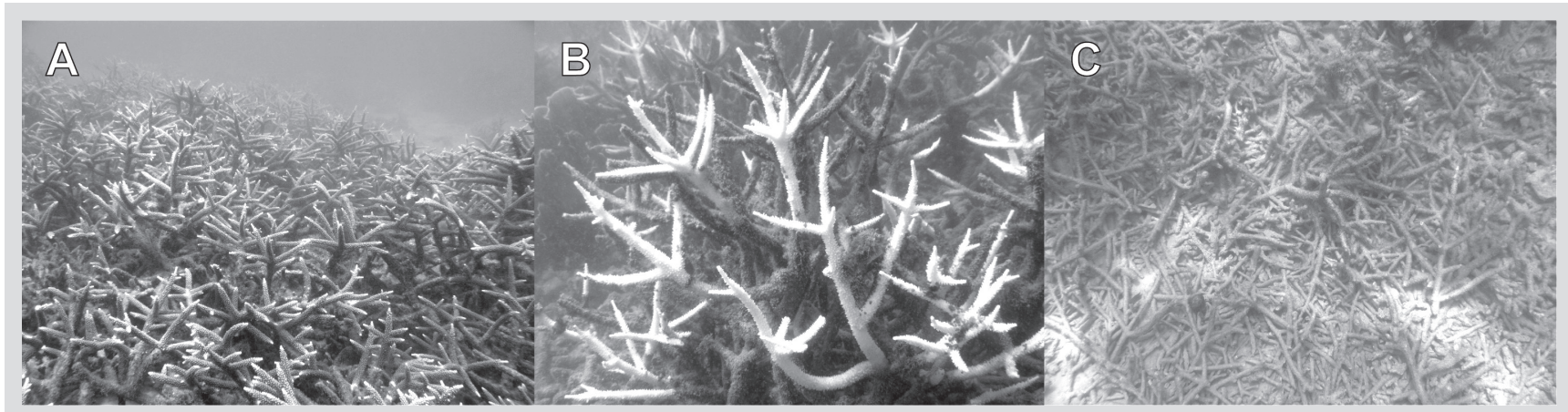

Figura 7. Formación de Acropora cervicornis en playa Pescador en la bahía de Nenguange. A) Septiembre de 2009 en buen estado. B) Septiembre de 2010 durante evento de blanqueamiento. C) Abril de 2011 Figure 7. Acropora cervicornis formation on Pescador Beach in Nenguange Bay. A) September 2009 in good condition. B) September muestra deterioro y pérdida importante. Fotos: Sven Zea.

2010 during bleaching event. C) April 2011 shows significant deterioration and loss. Photographs: Sven Zea.
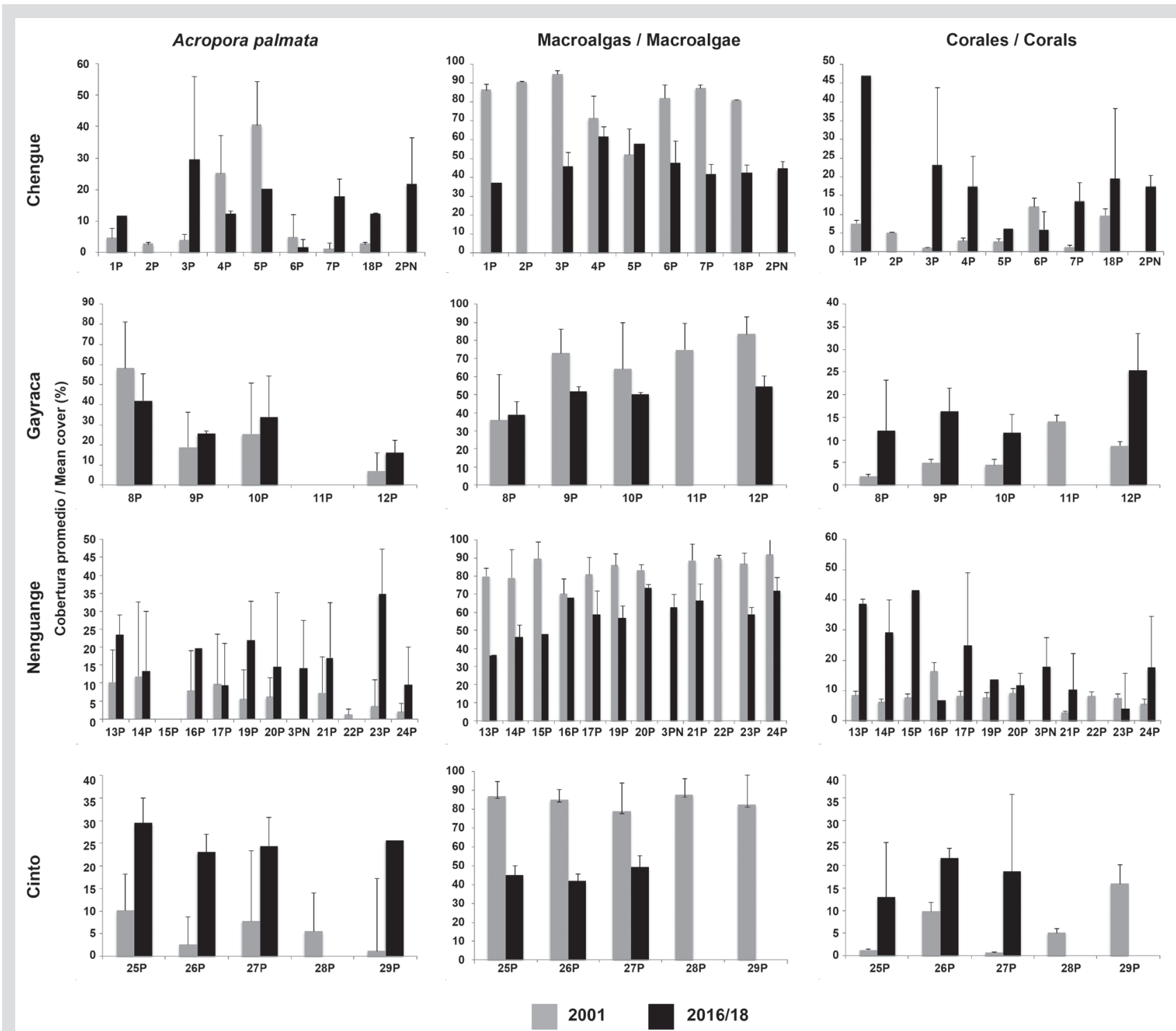

Figura 8. Cobertura promedio (\%) $+\mathrm{DE}$ de los principales componentes del sustrato (A. palmata, macroalgas y otros corales) en el PNNT entre 2001 (Garzón-Ferreria et al., 2004) y 2016/18.
Figure 8. Average coverage (\%) $+\mathrm{DE}$ of the main components of the substrate (A. palmata, macroalgae, and other corals) in TNNP between 2001 (Garzón-Ferreria et al., 2004) and 2016/18. 
mostraron una disminución significativa en todas las FAP a excepción de la $8 \mathrm{P}$ en Gayraca. La diferencia en total fue de $27 \%$ con respecto a 2001 (Prueba de Wilcoxon $\mathrm{T}_{23}=3,92 ; \mathrm{P}$ $<0,001)$. Con respecto a la cobertura de las otras especies de coral, el aumento fue de $12,8 \% \mathrm{y}$ se vio igualmente en todas las FAP a excepción de 6P en Chengue y 16P en Nenguange (Prueba de $\mathrm{t}$ de Student para muestras pareadas $\mathrm{t}_{23}=5,491 ; \mathrm{P}$ $<0,001$ ) (Figura 8). Las principales especies con coberturas de más de $2 \%$ fueron Millepora complanata, M. squarrosa, Siderastrea siderea, Pseudodiploria strigosa y P. clivosa (Material suplementario 2).

En cuanto a las formaciones registradas como adicionales al interior de las bahías del PNNT, la formación 2PN en Chengue presentó un porcentaje de A palmata, corales y macrolagas de 21,0,17,5 y 44,7\%, respectivamente, mientras en Nenguange la formación 3PN presentó valores de $14,3,17,8$ y $63,1 \%$, respectivamente (Figura 8 ). Para el sector de El Torín en isla Aguja la formación 1PN presentó una cobertura de $A$. palmata de $41,3 \%$, de macroalgas de $31,1 \%$ y de otros corales de $19,2 \%$, esta última compuesta principalmente por las especies Pseudodiploria clivosa y $P$. strigosa.

\section{Estructura poblacional de Acropora palmata}

Un total de 606 colonias fueron medidas. Las colonias $>10000 \mathrm{~cm}^{2}$ representaron un $32,0 \%$ de las colonias en todo el PNNT. En las bahías este porcentaje osciló entre 25,0 y 57,3 \%, siendo isla Aguja donde se encontró la mayor proporción de colonias grandes. Colonias pequeñas $\left(<100 \mathrm{~cm}^{2}\right)$ se encontraron en todas las bahías, a excepción de la bahía de Cinto (Figura 9). Hubo diferencias significativas en el tamaño de las colonias entre las diferentes bahías (Kruskal-Wallis $\mathrm{H}_{3}=30,2 \mathrm{P}<0,001$ ) y la prueba de Dunn por pares mostró a isla Aguja y Cinto como los sitios en donde se encontraron las colonias de mayor tamaño, y a Nenguange, Gayraca y Chengue como similares, con colonias en todos los intervalos de talla (datos sin transformar; Figura 9).

Los datos de tallas transformados logarítmicamente se distribuyeron en 11 intervalos de clase, entre 1,74 y 5,71 y estuvieron normalmente distribuidos en las bahías de Cinto, Nenguange y Gayraca. En Chengue e isla Aguja las tallas no mostraron una distribución normal (Tabla 1). Aunque se encontraron colonias grandes en todas las bahías, en isla Aguja y Gayraca se encontró el mayor porcentaje (16,3 y $13,2 \%$, respectivamente). Colonias pequeñas (i.e. en los tres primeros intervalos de clase) estuvieron presentes in Gayraca. The difference in total was $27 \%$ compared to 2001 (Wilcoxon $\mathrm{T}_{23}$ test $=3.92 ; \mathrm{P}<0.001$ ). Regarding the coverage of the other coral species, the increase was $12.8 \%$ and was seen equally in all the FAP except for $6 \mathrm{P}$ in Chengue and 16P in Nenguange ( $\mathrm{t}-$ Student test for paired samples $\mathrm{t} 23=5.491 ; \mathrm{P}<0.001)$ (Figure 8 ). The main species with covers of more than $2 \%$ were Millepora complanata, M. squarrosa, Siderastrea siderea, Pseudodiploria strigosa and P. clivosa (Supplementary Material 2).

Regarding the formations registered as additional to the interior of the TNNP bays, the $2 \mathrm{PN}$ formation in Chengue presented a percentage of $A$. palmata, corals, and macrolagas of $21.0,17.5$, and $44.7 \%$, respectively, while in Nenguange the 3PN formation presented values of 14.3, 17.8 and $63.1 \%$, respectively (Figure 8). For the El Torín sector in Aguja Island, the $1 \mathrm{PN}$ formation presented coverage of A. palmata of $41.3 \%$, macroalgae of $31.1 \%$, and other corals of $19.2 \%$, the latter composed mainly of the Pseudodiploria clivosa and P. strigosa species.

\section{Population structure of Acropora palmata}

A total of 606 colonies were measured. Colonies $>$ $10,000 \mathrm{~cm}^{2}$ represented $32.0 \%$ of the colonies in the entire TNNP. In the bays this percentage ranged between 25.0 and $57.3 \%$, being Aguja Island where the highest proportion of large colonies was found. Small colonies $\left(<100 \mathrm{~cm}^{2}\right)$ were found in all bays, except for Cinto bay (Figure 9). There were significant differences in the size of the colonies between the different bays (Kruskal-Wallis $\left.\mathrm{H}_{3}=30.2 \mathrm{P}<0.001\right)$ and Dunn's test by pairs showed Aguja and Cinto islands as the sites where the largest colonies were found, and Nenguange, Gayraca, and Chengue as similar, with colonies in all length intervals (untransformed data; Figure 9).

The logarithmically transformed length data were distributed in 11 class intervals, between 1.74 and 5.71, and were normally distributed in the bays of Cinto, Nenguange, and Gayraca. In Chengue and Aguja Island, the sizes did not show a normal distribution (Table 1). Although large colonies were found in all bays, the highest percentage was found on Aguja and Gayraca islands (16.3 and 13.2\%, respectively). Small colonies (i.e. in the first three-class intervals) were present in Nenguange $1.7 \%$, Chengue $6.3 \%$, and Gayraca $7.5 \%$ and absent in Cinto and Aguja Island (Figure 9). The negative bias was dominant in all bays with values between -0.022 and -0.312 , indicating the predominance of large colonies. For the bay of Cinto, the 

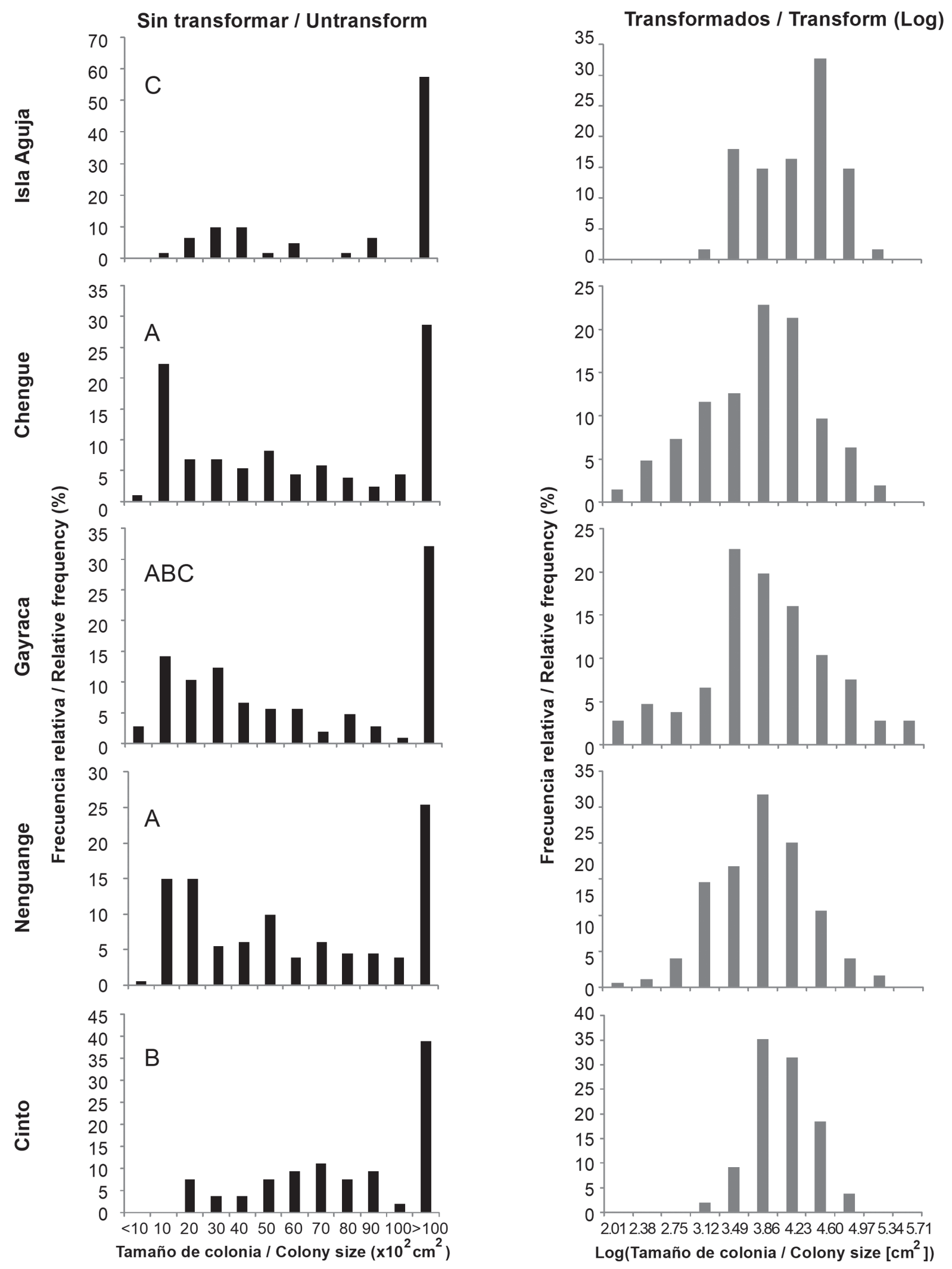

Figura 9. Distribución de frecuencias (\%) de talla de Acropora palmata para los datos sin transformar y transformados a logaritmo en base 10 en las bahías del PNNT. Letras sobre datos sin transformar indican el Figure 9. Frequency distribution (\%) of Acropora palmata for the untransformed data and logarithm transformed in base 10 in the bays of TNNP. Untransformed data above indicate the result of Dunn's post hoc resultado del análisis post hoc de Dunn de las tallas de colonias. analysis of colony sizes. 
en Nenguange 1,7\%, Chengue 6,3\% y Gayraca 7,5 \% y ausentes en Cinto e isla Aguja (Figura 9). El sesgo negativo fue dominante en todas las bahías con valores entre - 0,022 y $-0,312$, indicando la predominancia de colonias grandes. Para la bahía de Cinto el sesgo fue positivo $(0,124)$ aunque cercano al valor medio y con el menor coeficiente de variación $(9,75 \%)$, lo que se refleja en colonias de tamaño intermedio. La curtosis fue principalmente negativa a excepción de la bahía de Cinto $(0,041)$. En el resto de las bahías el coeficiente de variación (CV) osciló entre 16,7 y $21,7 \%$ (Tabla 1).

Tabla 1. Resumen estadístico de los datos de distribución de frecuencias de talla para las especies de Acropora en el PNNT. Convenciones: $\mathrm{n}=$ número de colonias. $\log _{10}=$ valor promedio del tamaño de las colonias previa transformación a logaritmo. $\mathrm{DE}=$ desviación estándar. $\mathrm{CV}=$ coeficiente de variación. $\mathrm{g}_{1}=$ sesgo. $\mathrm{g}_{2}=$ curtosis. Pnom (prueba de Kolmogorov-Smirnov con ajuste de Lilliefors) $=$ probabilidad de que los datos presenten una distribución normal. bias was positive (0.124) although close to the mean value, and with the lowest coefficient of variation $(9.75 \%)$, which is reflected in colonies of intermediate size. The kurtosis was mainly negative except for the Bay of Cinto (0.041). In the rest of the bays, the coefficient of variation (CV) ranged between 16.7 and $21.7 \%$ (Table 1).

\section{Acropora palmata condition}

A total of 595 colonies were evaluated, $58 \%$ were healthy, $20 \%$ with WPX lesions, $19 \%$ with damsel territories, and $3 \%$ with signs of predation by worms,

Table 1. Statistical summary of length frequency distribution data for Acropora species in the TNNP. Conventions: $\mathrm{n}=$ number of colonies. $\log _{10}=$ average value of the size of the colonies after transformation to logarithm. $\mathrm{SD}=$ standard deviation. $\mathrm{CV}=$ coefficient of variation. $\mathrm{g}_{1}=$ bias . $\mathrm{g}_{2}=$ kurtosis. Pnom (Kolmogorov-Smirnov test with Lilliefors adjustment) $=$ probability that the data present a normal distribution.

\begin{tabular}{|c|c|c|c|c|c|c|c|c|}
\hline Especie/Species & Bahía/Bay & n & Promedio/Average $\left(\log _{10}\right)$ & DE/SD & CV (\%) & $\mathbf{g}_{1}$ & $\mathbf{g}_{2}$ & Pnom \\
\hline \multirow{5}{*}{ Acropora palmata } & Cinto & 54 & 3,93 & 0,38 & 9,74 & 0,124 & 0,041 & 0,200 \\
\hline & Nenguange & 179 & 3,65 & 0,62 & 16,96 & $-0,022$ & $-0,060$ & 0,089 \\
\hline & Gayraca & 106 & 3,68 & 0,80 & 21,65 & $-0,041$ & $-0,038$ & 0,194 \\
\hline & Chengue & 206 & 3,61 & 0,73 & 20,15 & $-0,312$ & $-0,314$ & 0,000 \\
\hline & Isla Aguja & 61 & 4,07 & 0,54 & 13,68 & $-0,184$ & $-0,910$ & 0.008 \\
\hline \multirow{3}{*}{ Acropora cervicornis } & Cinto & 18 & 2,20 & 0,25 & 11,54 & 0,140 & $-0,858$ & 0,200 \\
\hline & Nenguange & 17 & 2,22 & 0,53 & 24,14 & $-0,146$ & $-1,639$ & 0,151 \\
\hline & Chengue & 13 & 2,42 & 0,21 & 8,78 & $-0,028$ & $-1,111$ & 0,200 \\
\hline
\end{tabular}

\section{Condición de Acropora palmata}

Se evaluó un total de 595 colonias, $58 \%$ estaban sanas, $20 \%$ con lesiones de WPX, $19 \%$ con territorios de peces damisela y $3 \%$ con signos de depredación por gusanos, caracoles y EBB. En isla Aguja se observó el mayor número de colonias sanas ( $85 \%$ ), siendo menor al interior de las bahías y oscilando entre $48 \%$ en la bahía de Gayraca y $69 \%$ en la bahía Chengue. Se observó igualmente una menor frecuencia de afectaciones en isla Aguja con $10 \%$ de las colonias con territorios de damiselas y $3 \%$ con WPX, mientras que en las cuatro bahías se observaron signos de depredación por invertebrados con baja frecuencia (entre 1,2 y $1,9 \%$ ). La EBB se observó en Chengue, Nenguange y Cinto con una frecuencia menor de $4 \%$, mientras que más de $10 \%$ de las colonias presentaron territorios de damiselas y la enfermedad de WPX (Figura 10). snails, and EBB. On Aguja Island, the highest number of healthy colonies ( $85 \%$ ) was observed, being less within the bays and oscillating between $48 \%$ in Gayraca Bay and $69 \%$ in Chengue Bay. A lower frequency of affectations was also observed in Aguja Island with $10 \%$ of the colonies with damsel territories and $3 \%$ with WPX, while in the four bays signs of predation by invertebrates were observed with low frequency (between 1.2 and 1,9\%). EBB was observed in Chengue, Nenguange, and Cinto with less than $4 \%$ frequency, while more than $10 \%$ of the colonies presented damsel territories and WPX disease (Figure 10).

\section{Acropora cervicornis cover}

The total average coverage of $A$. cervicornis of the TNNP of the previously described FACs, plus the additional formations located in the Bay of Chengue 


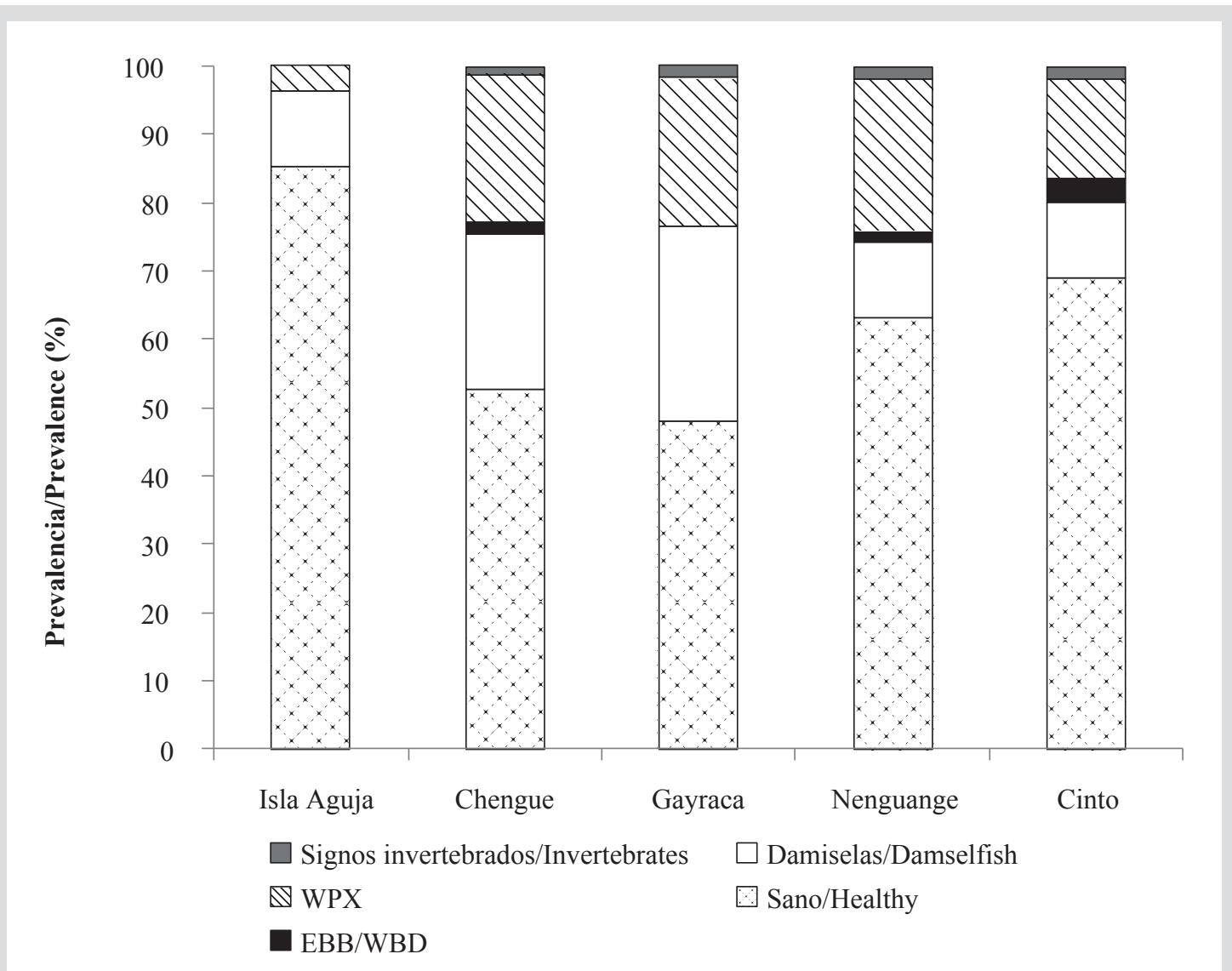

Figura 10. Porcentaje de las condiciones valoradas en Acropora palmata en el PNNT.
Figure 10. Percentage of the conditions valued in Acropora palmata in the TNNP.

\section{Cobertura de Acropora cervicornis}

La cobertura promedio total de $A$. cervicornis del PNNT de las FAC previamente descritas más las formaciones adicionales ubicadas en las bahías de Chengue y Cinto fue de $8,0 \pm 1,6 \%$. Las macroalgas cubrieron $39,1 \pm 4,9 \%$ y los corales 21,9 $\pm 5,0 \%$ del sustrato (Figura 11). La única FAC en que se logró comparar la cobertura con respecto a 2001 fue en Nenguange (7C), donde se encontró una reducción de $69,6 \%$ de $A$. cervicornis y de 51,2\% para las macroalgas, mientras en otros corales se encontró un incremento de $62 \%$, constituido por las especies Agaricia tenuifolia, Pseudodiploria strigosa, Madracis decactis, Millepora complanata, Montastraea cavernosa y Siderastrea siderea con más de $1 \%$ de cobertura. En las otras dos FAC en Nenguange (6C y 9C) solo fueron reconocibles esqueletos muertos. Las formaciones nuevas para las bahías de Cinto y Chengue presentaron coberturas vivas de $A$. cerviconis de 9,6 y $9,4 \%$ respectivamente, 19,9 y $24,0 \%$ de otros corales y 49,7 y $31,2 \%$ de macroalgas. and Cinto, was $8.0 \pm 1.6 \%$. Macroalgae covered $39.1 \pm$ $4.9 \%$ and corals $21.9 \pm 5.0 \%$ of the substrate (Figure 11). The only FAC in which it was possible to compare the coverage with respect to 2001 was in Nenguange (7C), where a reduction of $69.6 \%$ for $A$. cervicornis and $51.2 \%$ for macroalgae was found, while in other corals there was found an increase of $62 \%$, constituted by the species Agaricia tenuifolia, Pseudodiploria strigosa, Madracis decactis, Millepora complanata, Montastraea cavernosa and Siderastrea siderea with more than $1 \%$ coverage. In the other two FACs in Nenguange (6C and 9C) only dead skeletons were recognizable. The new formations for the Bays of Cinto and Chengue presented the live cover of A. cerviconis with 9.6 and $9.4 \%$ respectively, 19.9 and $24.0 \%$ of other corals and 49.7 and $31.2 \%$ of macroalgae.

\section{Population structure of Acropora cervicornis}

Only 48 colonies were measured, which had sizes between 23 and $890 \mathrm{~cm}^{2}$. The only FAC found among those registered by Garzón-Ferreira et al. (2004) was the 


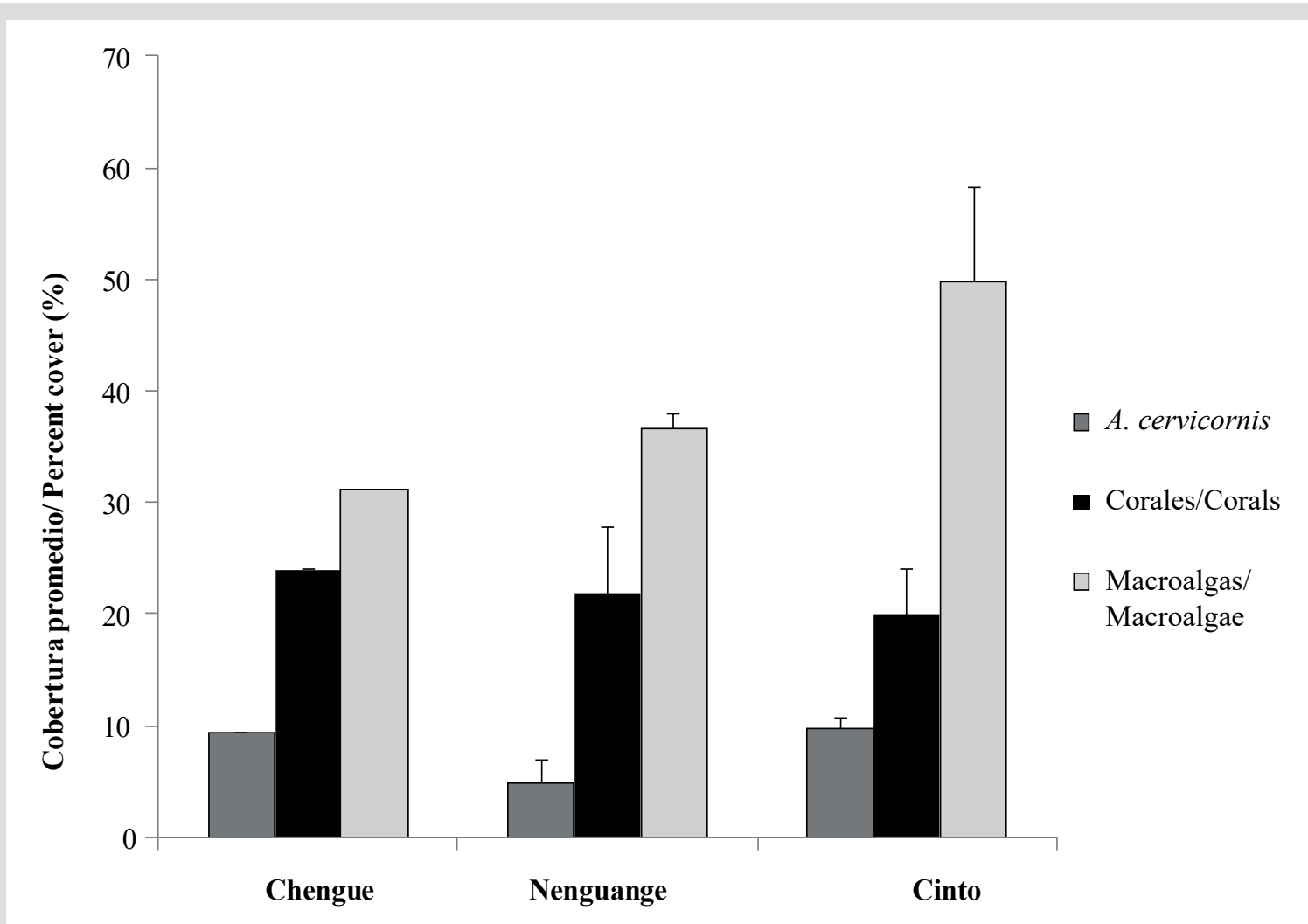

Figura 11. Cobertura relativa (\%) de los principales componentes del sustrato: Acropora cervicornis, macroalgas y otros corales en las formaciones de A. cervicornis el PNNT.
Figure 11. Relative coverage (\%) of the main components of the substrate: Acropora cervicornis, macroalgae and other corals in the $A$. cervicornis formations of the TNNP.

\section{Estructura poblacional de Acropora cervicornis}

Solo 48 colonias fueron medidas, las cuales tuvieron tallas entre 23 y $890 \mathrm{~cm}^{2}$. La única FAC encontrada de las registradas por Garzón-Ferreira et al. (2004) fue la 7C en la bahía de Nenguange, principalmente compuesta por colonias de tamaño pequeño $(47,0 \%, \mathrm{n}=8)$; el resto fueron colonias grandes $(53,0 \%, \mathrm{n}=9)$. En esta bahía se ha estado desarrollando una iniciativa de restauración para esta especie; sin embargo, no se tuvieron en cuenta estas colonias por provenir de fragmentaciones y estar en proceso de trasplante. Las formaciones nuevas evidenciadas en Cinto y Chengue estuvieron constituidas por colonias grandes en Chengue, y por colonias con una distribución de tallas más amplia en Cinto (Figura 11). El análisis de Kruskal-Wallis no mostró diferencias significativas en el tamaño de las colonias entre bahías $\left(\mathrm{H}_{2}=3,43, \mathrm{P}=0,179\right)$.

Las tallas de las colonias transformadas logarítmicamente se distribuyeron en siete intervalos de clase, entre 1,36 y 3,04 y estuvieron normalmente distribuidos en las tres bahías (Tabla 1). Nenguange y Cinto tuvieron una amplia distribución de tallas, mientras que Chengue presentó
7C in the Bay of Nenguange, mainly composed of small size colonies $(47.0 \%, \mathrm{n}=8)$; the rest were large colonies $(53.0 \%, \mathrm{n}=9)$. In this bay a restoration initiative for this species has been developing; however, these colonies were not taken into account because they came from fragmentation and were in the process of transplantation. The new formations evidenced at Cinto and Chengue consisted of large colonies at Chengue, and colonies with a broader size distribution at Cinto (Figure 11). The KruskalWallis analysis did not show significant differences in the size of the colonies among bays $(\mathrm{H} 2=3.43, \mathrm{P}=0.179)$.

The sizes of the logarithmically transformed colonies were distributed in seven class intervals, between 1.36 and 3.04, and were normally distributed in the three bays (Table 1). Nenguange and Cinto had a wide size distribution, while Chengue had colonies of intermediate size (Figure 12). The negative bias in Chengue and Nenguange with $g_{1}$ values between -0.028 and -0.146 indicates the predominance of large colonies. For Cinto Bay, the bias was positive $\left(g_{1}=0.140\right)$, which indicates the predominance of small colonies. The coefficient of 
colonias de talla intermedia (Figura 12). El sesgo negativo en Chengue y Nenguange con valores de $\mathrm{g}_{1}$ entre $-0,028$ y $-0,146$ indica la predominancia de colonias grandes. Para la bahía de Cinto el sesgo fue positivo $\left(g_{1}=0,140\right)$, lo cual indica la predominancia de colonias pequeñas. El coeficiente de variación fue mayor en Nenguange $(24,1 \%)$ y menor en Chengue $(8,8 \%)$ y la curtosis presentó valores negativos en las tres bahías (Tabla 1). variation was higher in Nenguange $(24.1 \%)$ and lower in Chengue $(8.8 \%)$ and the kurtosis presented negative values in the three bays (Table 1).

Acropora cervicornis status

A total of 159 living colonies were evaluated in Bays of Chengue $(n=38)$, Cinto $(n=48)$ and Nenguange $(\mathrm{n}=73)$. Of these, $33 \%$ were in good health, $23 \%$ had

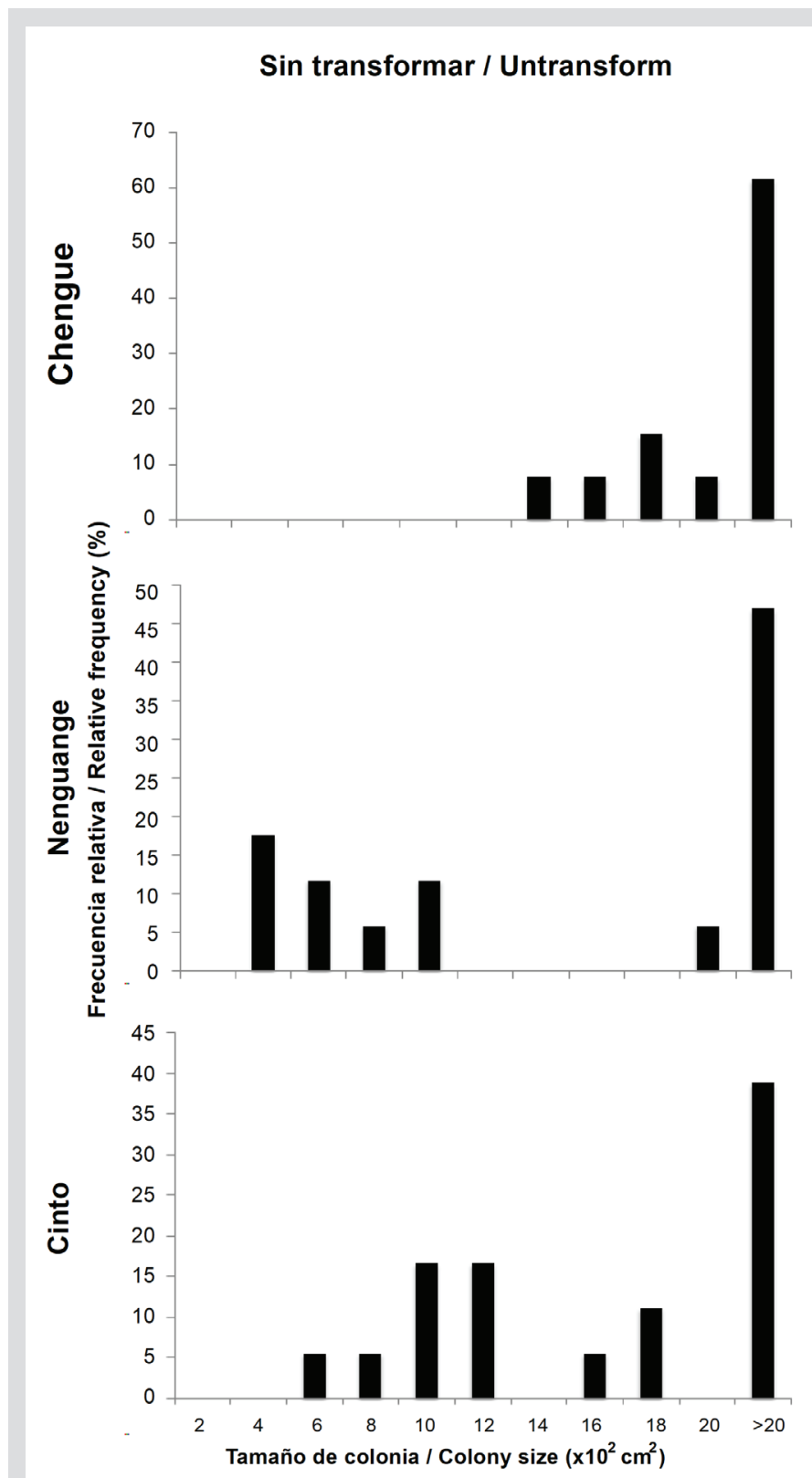

Figura 12. Distribución de frecuencias de talla de Acropora cervicornis para los datos sin transformar y transformados $\left(\log _{10}\right)$ en el PNNT.
Transformados / Transform (Log)
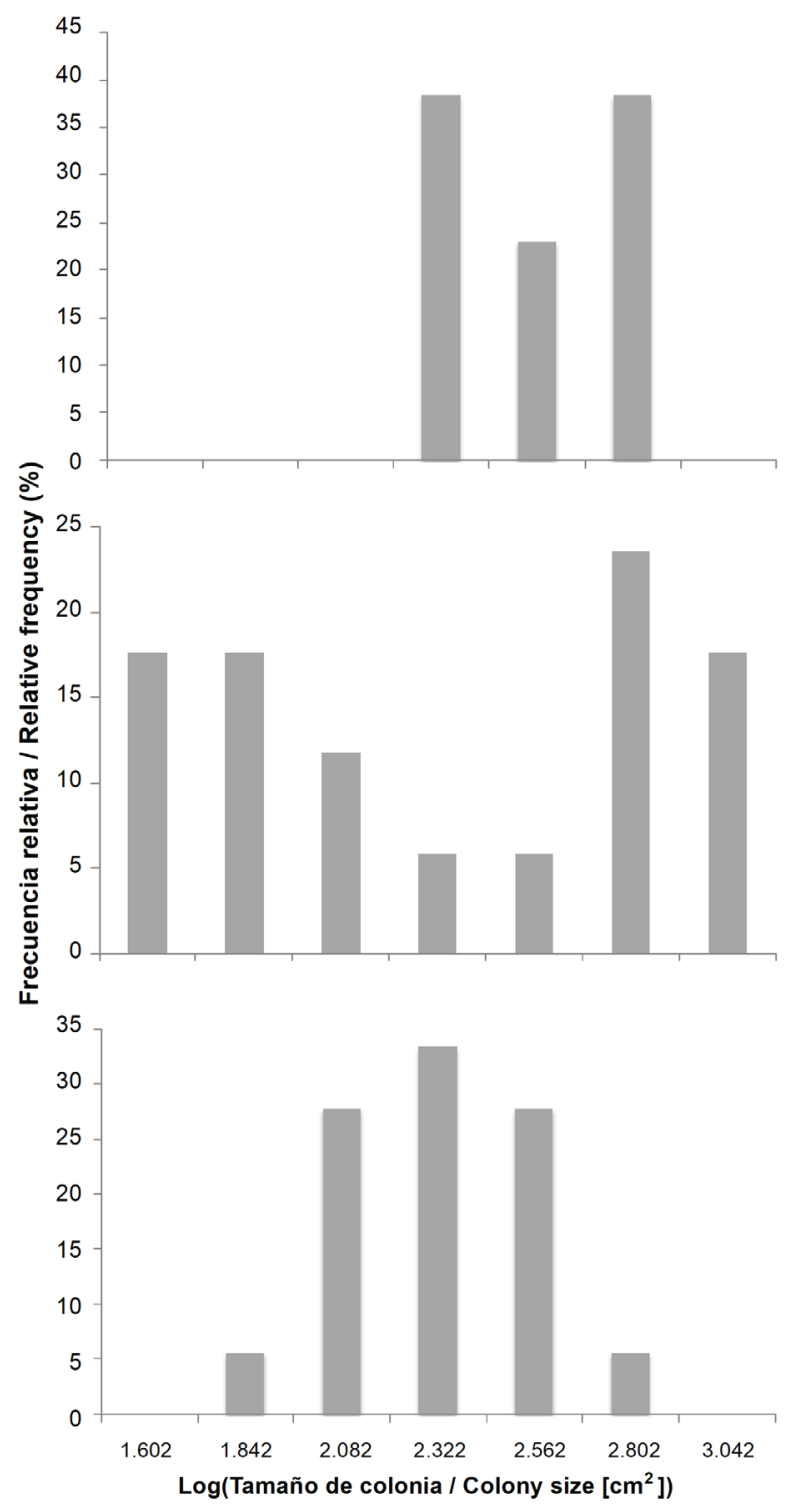

Figure 12. Distribution of length frequencies of Acropora cervicornis for the untransformed and transformed data $\left(\log _{10}\right)$ in the TNNP. 


\section{Condición de Acropora cervicornis}

Un total de 159 colonias vivas fueron evaluadas en las bahías de Chengue $(\mathrm{n}=38)$, Cinto $(\mathrm{n}=48)$ y Nenguange $(n=73)$. De estas, $33 \%$ se encontraron en buen estado de salud, $23 \%$ presentaron macroalgas, $17 \%$ tuvieron territorios de damisela y $14 \%$ presentaron signos de depredación por invertebrados. Finalmente, $13 \%$ de las colonias presentaron EBB o blanqueamiento. Por bahías, Cinto presentó el menor porcentaje de colonias en buen estado de salud (21\%), así como la mayor prevalencia de colonias con macroalgas ( $29 \%$ ) y con signos de depredación por invertebrados (23\%). La bahía de Nenguange fue la que presentó la mayor afectación de la EBB (12\%) y junto con Cinto presentaron blanqueamiento, pero este no se observó en Chengue (Figura 13). macroalgae, $17 \%$ had damsel territories, and $14 \%$ showed signs of predation by invertebrates. Finally, $13 \%$ of the colonies presented EBB or bleaching. By bays, Cinto had the lowest percentage of colonies in good health $(21 \%)$, as well as the highest prevalence of colonies with macroalgae (29 \%) and with signs of predation by invertebrates (23\%). The Nenguange Bay was the one that presented the greatest involvement of the EBB (12\%) and together with Cinto they presented whitening, but this was not observed in Chengue (Figure 13).

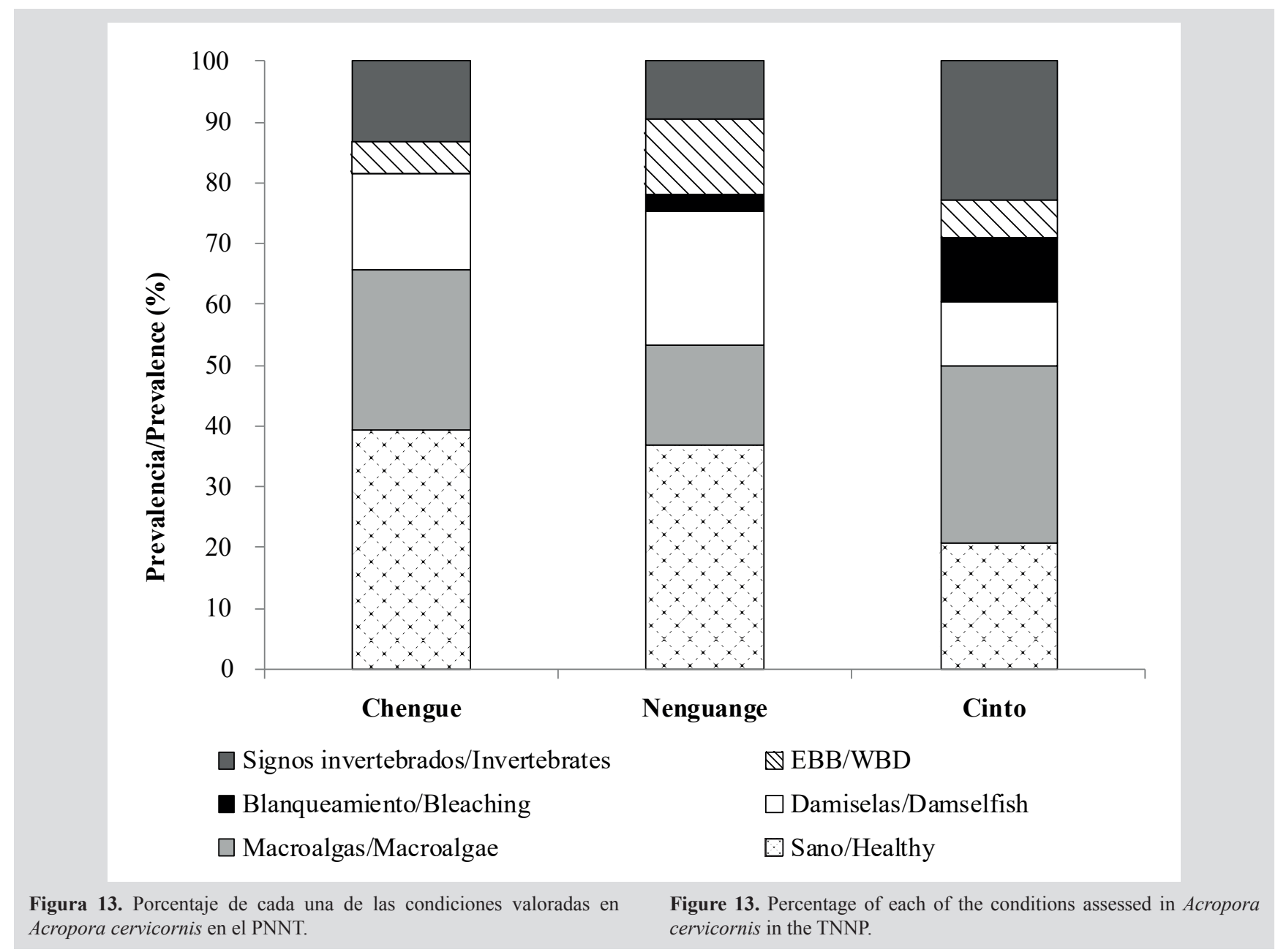

Figura 13. Porcentaje de cada una de las condiciones valoradas en Acropora cervicornis en el PNNT.
Figure 13. Percentage of each of the conditions assessed in Acropora cervicornis in the TNNP. 


\section{DISCUSIÓN}

La mortalidad de las especies de Acropora en todo el Caribe fue registrada desde el inicio de la década de 1980. A la fecha, pocos estudios han documentado la recuperación o pérdida progresiva de las poblaciones de estas especies. Por lo anterior, el estudio realizado por Garzón-Ferreira et al. (2004) se constituye en un referente que permite, en conjunto con este estudio, conocer de forma comparativa el cambio que han sufrido y el estado actual de las poblaciones de Acropora palmata y A. cervicornis en el PNNT.

Aunque la estimación de las áreas fue realizada con métodos distintos, la fotografía aérea permite estimar el área, y como cualquier método siempre existe un margen de error respecto al tamaño que realmente ocupa un ecosistema; sin embargo, se obtuvo una aproximación de las áreas potenciales de muy buena resolución, principalmente de las formaciones de $A$. palmata, al ser hábitats someros. Selgrath et al. (2016) recomiendan el uso de sensores remotos cuando se desea una mejor precisión. Además, Ekebom y Enkkilä (2003) mencionan cómo la resolución de imágenes aéreas provee información suficiente para una identificación confiable del hábitat. Para A. palmata, Garzón-Ferreira et al. (2004) registraron un área de $119319 \mathrm{~m}^{2}$ y para $A$. cervicornis de $1200 \mathrm{~m}^{2}$; los datos en este estudio demuestran que estas formaciones han sufrido una reducción de $30 \%$ y 99,3\%, respectivamente.

Aunque ha habido una reducción general del área ocupada por A. palmata, esta especie continúa cubriendo un área significativa en el PNNT. La reducción es debida a la disminución del tamaño de 14 formaciones y a que no se encontraron seis que fueron evaluadas en 2001 (GarzónFerreira et al., 2004). Sin embargo, nueve formaciones mostraron un aumento en su área, que sumado a la inclusión de la formación 20P en Nenguange (la cual no fue tenida en cuenta en 2001), y dos nuevas formaciones (una en Chengue y otra en isla Aguja), dan lugar a un área total de casi $85000 \mathrm{~m}^{2}$ de A. palmata en el PNNT en comparación con los $119319 \mathrm{~m}^{2}$ estimados en 2001 (Garzón-Ferreira et al., 2004). Si bien en algunas FAP individuales se encontró una reducción de la cobertura, la tendencia en la mayoría de las formaciones fue de aumento, con una cobertura general de $17,0 \%$ en 2001, a casi $20,0 \%$ en este estudio. Así mismo, las macroalgas que cubrían $80 \%$ del sustrato pasaron a $50 \%$. Vega-Sequeda et al. (2008) registraron igualmente menores coberturas de macroalgas: $32,4 \%$ en Gayraca y $67,4 \%$ en Cinto. Los corales aumentaron en $12,8 \%$ con respecto a lo reportado por Garzón-Ferreira (2004), y su composición,

\section{DISCUSSION}

The mortality of Acropora species throughout the Caribbean was recorded since the early 1980s. To date, few studies have documented the progressive recovery or loss of populations of these species. Therefore, the study carried out by Garzón-Ferreira et al. (2004) constitutes a reference that allows, together with this study, to know comparatively the change that they have suffered and the current state of the populations of Acropora palmata and A. cervicornis in the TNNP.

Although the estimation of the areas was carried out with different methods, aerial photography allows estimating the area, and like any method, there is always a margin of error regarding the size that an ecosystem occupies; However, an approximation of the potential areas of the very good resolution was obtained, mainly of the A. palmata formations, as they are shallow habitats. Selgrath et al. (2016) recommend the use of remote sensors when better precision is desired. In addition, Ekebom and Enkkilä (2003) mention how the resolution of aerial images provides sufficient information for reliable identification of the habitat. For A. palmata, GarzónFerreira et al. (2004) recorded an area of $119319 \mathrm{~m}^{2}$ and for A. cervicornis of $1200 \mathrm{~m}^{2}$. The data in this study show that these formations have suffered a reduction of $30 \%$ and $99.3 \%$, respectively.

Although there has been a general reduction in the area occupied by $A$. palmata, this species continues to cover a significant area in the TNNP. The reduction is due to the decrease in the size of 14 formations and the fact that six were not found in the 2001 evaluation (GarzónFerreira et al. 2004). However, nine formations showed an increase in their area, which added to the inclusion of the 20P formation in Nenguange (which was not taken into account in 2001), and two new formations (one in Chengue and the other in Aguja Island), they gave rise to a total area of almost $85000 \mathrm{~m}^{2}$ of A. palmata in the TNNP compared to the $119319 \mathrm{~m}^{2}$ estimated in 2001 (Garzón-Ferreira et al. 2004). Although a reduction in coverage was found in some individual FAPs, the trend in most formations was upward, with an overall coverage from $17.0 \%$ in 2001 to almost $20.0 \%$ in this study. Likewise, the macroalgae that covered $80 \%$ of the substrate went to $50 \%$. Vega-Sequeda et al. (2008) also registered lower macroalgae coverage: $32.4 \%$ in Gayraca and $67.4 \%$ in Cinto. Corals increased by $12.8 \%$ with respect to that reported by Garzón-Ferreira (2004), and their composition, taking into account the 
teniendo en cuenta las especies con mayor cobertura, ha permanecido estable debido a que tanto $M$. complanata $(3,5$ y $7,9 \%)$, S. siderea (2,5 y $5,0 \%)$ y P. strigosa $(1,2$ y $8,6 \%$ ) siguen siendo las especies que permanecen como los principales componentes de las FAP. Sin embargo, se hubiese esperado que $M$. complanata, al tener cortos periodos larvales (Lewis, 1989), o Porites astreoides, con una estrategia de autofertilización (Doropoulus et al., 2015), hubiesen continuado colonizando el sustrato disponible, tal como ha sido visto en crestas arrecifales de Cuba (CaballeroAragón, 2020), pero en el PNNT ambas especies se han reducido.

La frecuencia de colonias de tamaño grande $\left(>10000 \mathrm{~cm}^{2}\right)$ de A. palmata en el PNNT entre 25,0 y $57,3 \%$ es alta en comparación con otros estudios que han abordado la distribución de frecuencias de talla a nivel regional. Esto es muy importante, teniendo en cuenta que la estructura tridimensional de las colonias de esta especie aporta complejidad y funcionalidad ecológica al ecosistema. Por ejemplo, es de esperarse que estas colonias tengan un alto potencial reproductivo, ya que ellas son fértiles a partir de $1000 \mathrm{~cm}^{2}$ (Soong y Lang, 1992), y en el PNNT 79,8 \% tuvieron tallas mayores a $1000 \mathrm{~cm}^{2}$. A pesar de que distinguir nuevos reclutas es difícil, se observaron colonias pequeñas colonizando espacios disponibles. Además, la distribución normal de los datos transformados a logaritmo y las variables de asimetría y curtosis negativo, también dan cuenta de un buen estado de la población, con una posible transición de clases de talla más rápida como resultado de su rápido crecimiento. Knowlton (2001) menciona que, para que una población pueda recuperarse, necesita estar dominada por colonias sanas y caracterizadas por una amplia distribución de frecuencia de tallas como fue la tendencia encontrada en este estudio.

El resultado de tallas grandes igualmente puede obedecer al régimen de perturbación a los cuales están sometidos los arrecifes. Gardner et al. (2005), quienes modelaron la información de 286 arrecifes a lo largo del Caribe entre 1980 y 2001, encontraron cómo 177 sitios experimentaron el impacto de huracanes con una reducción de cobertura en promedio de $17 \%$. Lo anterior conlleva a la fragmentación de colonias y a la generación de colonias pequeñas. Vardi et al. (2012) valoraron entre 2004 y 2010 las poblaciones de A. palmata en los cayos de la Florida observando la reducción en la cobertura, colonias de tallas entre 100 y $\left.900 \mathrm{~cm}^{2} \approx 32 \%\right)$ y dominancia de colonias pequeñas de $<100 \mathrm{~cm}^{2}(56 \%)$. Si bien es muy infrecuente species with greater coverage, has remained stable because both $M$. complanata (3.5 and $7.9 \%$ ), S. siderea (2.5 and $5.0 \%$ ) and P. strigosa (1.2 and 8.6\%) continue to be the species that remain the main components of FAP. However, it would have been expected that $M$. complanata, having short larval periods (Lewis, 1989), or Porites astreoides, with a self-fertilization strategy (Doropoulus et al. 2015), would have continued to colonize the available substrate, as has been seen in reef ridges of Cuba (Caballero-Aragón, 2020), but in the TNNP both species have been reduced.

The frequency of large colonies $\left(>10000 \mathrm{~cm}^{2}\right)$ of A. palmata in the TNNP between 25.0 and $57.3 \%$ is high compared to other studies that have addressed the distribution of length frequencies at the regional level. This is very important, taking into account that the threedimensional structure of the colonies of this species brings complexity and ecological functionality to the ecosystem. For example, it is expected that these colonies have a high reproductive potential, since they are fertile from 1000 $\mathrm{cm}^{2}$ (Soong and Lang, 1992), and in the TNNP $79.8 \%$ had sizes greater than $1000 \mathrm{~cm}^{2}$. Although distinguishing new recruits is difficult, small colonies were observed colonizing available spaces. Also, the normal distribution of the data transformed to logarithm, and the variables of skewness and negative kurtosis show a good state of the population, with a possible faster transition of length classes as a result of its rapid growth. Knowlton (2001) mentioned that for a population to recover, it needs to be dominated by healthy colonies characterized by a wide size-frequency distribution, as was the trend found in this study.

The result of large sizes can also be due to the disturbance regime to which the reefs are subjected. Gardner et al. (2005), who modeled the information of 286 reefs throughout the Caribbean between 1980 and 2001, found how 177 sites experienced the impact of hurricanes with a reduction of coverage in average of $17 \%$. This leads to the fragmentation of colonies and the generation of small colonies. Vardi et al. (2012) evaluated the populations of A. palmata in the Florida Keys between 2004 and 2010, observing the reduction in coverage, colonies of sizes between 100 and $900 \mathrm{~cm}^{2}(\approx 32 \%)$, and dominance of small colonies $<100 \mathrm{~cm}^{2}(56 \%)$. Although the passage of hurricanes along the continental coast of the Colombia Caribbean is very infrequent (Ortíz-Royero, 2007), in Santa Marta there have been hurricanes like Matthew in October 2016. Although this generated the breakdown 
el paso de huracanes por la costa continental del Caribe colombiano (Ortíz-Royero, 2007), en Santa Marta sí se han dado coletazos de huracanes como Matthew en octubre de 2016. Aunque este generó el rompimiento de colonias, tal como fue observado en isla Aguja, no existían datos de cobertura ni de la distribución de frecuencia de tallas que permitieran evaluar los efectos de este evento. Sin embargo, los datos de este estudio muestran la resiliencia de esta población de A. palmata, ya que la valoración en 2018 da cuenta de colonias de gran tamaño y una pronta recuperación.

En cuanto a la condición de las poblaciones de A. palmata, se destaca su afectación por los depredadores comunes descritos para la especie en el Caribe (Knowlton et al., 1990). Aunque las formaciones presentan un buen estado de salud, una importante proporción de colonias presentan el establecimiento de territorios de peces damisela (Stegastes spp.), evidenciado por las lesiones en forma de "chimeneas" sobre la superficie del tejido coralino (Kramer et al., 2008). Según Ceccarelli et al. (2005), esto puede ser negativo, dado que los peces territoriales (damiselas) excluyen a los peces herbívoros ramoneadores, y en su ausencia incrementa la biomasa de macroalgas con una consecuente disminución del tejido coralino. Aunque este estudio mostró una menor cobertura de macroalgas, es recomendable seguir adelantando estudios que evalúen este efecto en las FAP del PNNT.

La enfermedad de WPX se ha postulado como una de las principales causas de la pérdida poblacional de Acropora en el Caribe (Bruckner y Bruckner, 1997; Rodríguez-Martínez et al., 2001; Patterson et al., 2002). En el PNNT varias colonias presentaron la enfermedad; sin embargo, estas lesiones afectaron $<10 \%$ del tejido coralino vivo, y durante el estudio se observó su reducción y en algunos casos su desaparición, lo cual coincide con Rogers y Muller (2012) quienes observaron cómo $A$. palmata se recupera de lesiones de WPX en un tiempo de 1,7 meses. Las colonias del PNNT están influenciadas por la disminución de la temperatura en la época de surgencia entre los meses de diciembre a abril (Bayraktarov et al., 2014b) y como proponen Muller y van Woesik (2014), la severidad, frecuencia, y recuperación de esta patología se encuentra relacionada con anomalías térmicas, lo que plantea un escenario favorable, puesto que estos descensos de temperatura pueden otorgarle una ventaja en la salud poblacional.

En contraste con $A$. palmata, la situación es evidentemente grave para A. cervicornis. Para esta especie, of colonies, such as was observed in Aguja Island, there were no coverage data or the length-frequency distribution that would allow evaluating the effects of this event. However, the data from this study show the resilience of this population of A. palmata, since the assessment in 2018 shows large colonies and a quick recovery.

Regarding the condition of the A. palmata populations, its affectation by the common predators described for the species in the Caribbean stands out (Knowlton et al., 1990). Although the formations are in good health, a significant proportion of colonies show the establishment of damselfish (Stegastes spp.) Territories, evidenced by the lesions in the form of "chimneys" on the surface of the coral tissue (Kramer et al., 2008). According to Ceccarelli et al. (2005), this may be negative, given that territorial fish (damsels) exclude herbivorous browsing fish, and in their absence increases the biomass of macroalgae with a consequent decrease in coral tissue. Although this study showed fewer macroalgae coverage, it is advisable to continue carrying out studies evaluating this effect on the TNNP FAP.

WPX disease has been postulated as one of the main causes of Acropora population loss in the Caribbean (Bruckner and Bruckner, 1997; Rodríguez-Martínez et al., 2001; Patterson et al., 2002). In the TNNP several colonies presented the disease; however, these lesions affected $<10 \%$ of the living coral tissue, and during the study its reduction and in some cases its disappearance was observed, which coincides with Rogers and Muller (2012) who observed how A. palmata recovers from lesions of WPX in a time of 1.7 months. The colonies of the TNNP are influenced by the decrease in temperature in the period of upwelling between December to April (Bayraktarov et al., 2014b) and as proposed by Muller and van Woesik (2014), the severity, frequency, and recovery of this pathology are related to thermal anomalies, which poses a favorable scenario, since these temperature drops can give it an advantage in population health.

In contrast to A. palmata, the situation is dire for A. cervicornis. For this species, although 12 formations had been registered and not all with living cover, the criteria for its definition was given by the presence of recognizable skeletons. To date, only one formation of this type has been established with a reduction in $83 \%$ of the area. Despite this, two different formations were located in Cinto Bay and the presence of isolated colonies in Chengue. In Nenguange, initiatives are carried out by 
aunque se habían registrado 12 formaciones y no todas con cobertura viva, el criterio para su definición estuvo dado por la presencia de esqueletos reconocibles. A la fecha, solo se logró establecer una formación de este tipo con una reducción en área de $83 \%$. A pesar de ello, se ubicaron dos formaciones distintas en la bahía de Cinto y la presencia de colonias aisladas en Chengue. En Nenguange se llevan a cabo iniciativas por la Unidad de Parques Nacionales Naturales de Colombia a fin de repoblar la especie; sin embargo, se requieren registros de supervivencia que provean información sobre el éxito del programa. La reducción en cobertura fue también significativa. El único sitio en el que se cuantificó fue en Nenguange, que pasó de 40,5 \% (Garzón-Ferreira et al., 2004) a 4,8 \%, mientras que las formaciones nuevas en Chengue y Cinto no alcanzaron $10 \%$. La tendencia de reducción de macroalgas y aumento de corales fue similar a lo descrito en A. palmata y estas formaciones estuvieron además compuestas por M. complanata, Orbicella annularis, Colpophillia natans, Diploria labyrinthiformis y P. strigosa, siendo especies comúnmente presentes en las formaciones evaluadas por Garzón-Ferreira et al. (2004).

El número de colonias encontrado fue reducido en las tres bahías donde se encontró $A$. cervicornis, representada por colonias grandes y sin evidencia de reclutas. En general, para todo el Caribe, esta especie ha mostrado signos de mayor deterioro y se han evidenciado pérdidas importantes por eventos de blanqueamiento y enfermedades. En la región de Santa Marta, Rodríguez-Ramírez et al. (2008) en el PNNT en 2003 mencionaron una incidencia de blanqueamiento de 2,9 \% y en la bahía de Chengue el Sistema Nacional de Monitoreo de Arrecifes de Coral (SIMAC) en 2010 registró cerca de $18 \%$ de corales blanqueados. Se ha atribuido a la temperatura como la principal causa de deterioro; sin embargo, Romero-Rodríguez et al. (2014) incorporaron diferentes variables ambientales en series de datos entre 1998 y 2010, y encontraron que además de la temperatura, las descargas continentales influyen en el blanqueamiento. Para 2005 (entre septiembre y noviembre) y 2010 (agosto, noviembre y diciembre), se registró blanqueamiento. Si bien no hay evidencia del deterioro de la especie en 2005, las series de tiempo muestran cómo una formación en buen estado en 2009 pasó en 2010 a presentar blanqueamiento y en abril de 2011 a prácticamente desaparecer. Estos registros son una evidencia del deterioro, sin embargo, son muchos más los efectos combinados que han llevado a la reducción de las poblaciones. the National Natural Parks Unit of Colombia to repopulate the species; however, survivorship records are required to provide information on the success of the program. The reduction in coverage was also significant. The only site where it was quantified was in Nenguange, which went from $40.5 \%$ (Garzón-Ferreira et al., 2004) to $4.8 \%$, while the new formations in Chengue and Cinto did not reach $10 \%$. The trend of reduction of macroalgae and increase of corals was similar to that described in A. palmata and these formations were also composed of M. complanata, Orbicella annularis, Colpophillia natans, Diploria labyrinthiformis, and P. strigosa, being species commonly present in the formations. evaluated by Garzón-Ferreira et al. (2004).

The number of colonies found was reduced in the three bays where $A$. cervicornis was found, represented by large colonies and no evidence of recruits. In general, for the entire Caribbean, this species has shown signs of further deterioration and significant losses have been evidenced by bleaching events and diseases. In the Santa Marta region, Rodríguez-Ramírez et al. (2008) in the TNNP in 2003 mentioned an incidence of bleaching of $2.9 \%$ and in Chengue Bay the National Coral Reef Monitoring System (SIMAC) in 2010 recorded about $18 \%$ of bleached corals. The temperature has been attributed as the main cause of deterioration; however, Romero-Rodríguez et al. (2014) incorporated different environmental variables in data series between 1998 and 2010, and found that in addition to temperature, continental discharges influence bleaching. For 2005 (between September and November) and 2010 (August, November, and December), bleaching was recorded. Although there is no evidence of deterioration of the species in 2005, the time series shows how a formation in good condition in 2009 passed in 2010 to present whitening and in April 2011 to practically disappear. These records are evidence of deterioration, however, many more combined effects have led to population declines.

When the condition of A. cervicornis was evaluated, the average of colonies with territories of Stegastes spp. was $17 \%$ and with macroalgae $22 \%$. This may be the result of the territorial behavior of damselfish, which excludes the browsing reef herbivores (Ceccarelli et al., 2005), and which increases macroalgae (Hoey and Bellwood, 2010). Mejía-Niño and Garzón-Ferrerira (2003) already showed in the TNNP how from the evaluated alga-coral interactions, leafy algae predominated, causing physical damage by abrasion; however, there are no direct 
Cuando se evaluó la condición de $A$. cervicornis, el promedio de colonias con territorios de Stegastes spp. fue de $17 \%$ y con macroalgas $22 \%$. Esto puede ser resultado del comportamiento de territorialidad de los peces damisela, que excluye a los herbívoros arrecifales ramoneadores (Ceccarelli et al., 2005), y que resulta en un incremento de macroalgas (Hoey y Bellwood, 2010). Mejía-Niño y Garzón-Ferrerira (2003) ya mostraban en el PNNT cómo de las interacciones evaluadas alga-coral predominaban algas frondosas que ocasionaban daños físicos por abrasión; sin embargo, no hay evaluaciones directas al respecto que puedan dar indicios si estas interacciones están en las causas que han comprometido estas poblaciones. Al respecto, Schopmeyer y Lirman (2015) documentaron la prevalencia de los peces damisela y los efectos negativos de los céspedes algales en A. cervicornis a lo largo de los cayos de Florida. Los resultados mostraron cómo la ocupación por los peces fue la principal causa de mortalidad (34,6\%) en aquellas colonias evaluadas con signos de estrés, comparado con enfermedades (1,6\%), recubrimiento de algas/esponjas $(5,6 \%)$ o depredación por invertebrados coralívoros (7,9\%). La presencia del caracol Coralliophilia erosa y otros invertebrados, así como las lesiones derivadas, fueron evidentes en este estudio (14,5\%) y aunque Schopmeyer y Lirman (2015) obtuvieron resultados similares y sugieren que la disminución de la depredación de caracoles se debe a la presencia de peces damisela, es necesario evaluar esto a mediano y largo plazo para obtener evidencias sobre el impacto en la salud poblacional. Los depredadores reportados contribuyen al deterioro poblacional de $A$. cervicornis que, sumado a su baja cobertura, demuestra la crítica condición de esta especie en el PNNT.

En general, aunque la EBB no fue una condición tan evidente; su manifestación puede deberse al incremento en patógenos que puedan estar albergados en las macroalgas como lo demuestran Sweet et al. (2013). Esos autores sugieren que algas y corales hospedan grupos procariotas diferentes y que dentro del microbioma de las algas residen grupos potencialmente patógenos para corales. Sin embargo, Nugues et al. (2004) mencionan que debe haber un estrés físico como requisito previo para que exista una transmisión de patógenos entre alga y coral. Durante este estudio no se registró la temperatura, y debido a que el área del PNNT está sujeta a la dinámica estacional de surgencia de aguas relativamente frías (Bayraktarov et al., 2014b), se requiere la medición periódica de algunas variables que, para el caso crítico de $A$. cervicornis, puedan tenerse en cuenta en los evaluations in this regard that can give indications if these interactions are in the causes that have compromised these populations. In this regard, Schopmeyer and Lirman (2015) documented the prevalence of damselfish and the negative effects of algal grasses on $A$. cervicornis along with the Florida Keys. The results showed how the occupation by fish was the main cause of mortality (34.6\%) in those colonies evaluated with signs of stress, compared to diseases (1.6\%), algae/sponge coating $(5.6 \%)$, or predation by corallivorous invertebrates (7.9\%). The presence of the snail Coralliophila erosa and other invertebrates, as well as the resulting injuries, were evident in this study (14.5\%) and, although Schopmeyer and Lirman (2015) obtained similar results and suggest that the decrease in snail predation is due to the presence of damselfish, it is necessary to evaluate this in the medium and long term to obtain evidence on the impact on population health. The reported predators contribute to the population decline of $A$. cervicornis, which, added to its low coverage, demonstrates the critical condition of this species in the TNNP.

In general, although EBB was not such an evident condition, its manifestation may be due to the increase in pathogens that may be harbored in macroalgae as demonstrated by Sweet et al. (2013). These authors suggest that algae and corals host different prokaryotic groups and that potentially pathogenic groups for corals reside within the microbiome of algae. However, Nugues et al. (2004) mentioned that there must be physical stress as a prerequisite for there to be a transmission of pathogens between algae and coral. During this study, the temperature was not recorded, and, since the TNNP area is subject to the seasonal dynamics of upwelling of relatively cold waters (Bayraktarov et al., 2014b), the periodic measurement of some variables is required, which for the critical case of $A$. cervicornis, can be taken into account in restoration programs and allow decisions to be made that can help with its maintenance.

\section{ACKNOWLEDGEMENTS}

This work was financed by Colciencias (code 11177141011) and the Universidad del Magdalena within the framework of the project "Acropora: key gender for conservation: genetic diversity, connectivity, and updating of its populations in the Colombian Caribbean". The authors thank to the National Natural Parks Unit of 
programas de restauración y permitan tomar decisiones que puedan ayudar a su mantenimiento.

\section{AGRADECIMIENTOS}

Este trabajo fue financiado por Colciencias (código 11177141011) y la Universidad del Magdalena en el marco del proyecto "Acropora: género clave para la conservación. Diversidad genética, conectividad y actualización de sus poblaciones en el Caribe colombiano". Los autores agradecen a la Unidad de Parques Nacionales Naturales de Colombia (permiso 001 del 6 de marzo de 2017) y al grupo de investigación Ecología y Diversidad de Algas Marinas y Arrecifes Coralinos.
Colombia (permit 001 of March 6, 2017) and the research group Ecology and Diversity of Marine Algae and Coral Reefs.

\section{BIBLIOGRAFÍA/LITERATURE CITED}

Adjeroud, M., M.S Pratchett, M.C. Kospartov, C. Lejeusne, and L. Penin L. 2007. Small-scale variability in the size structure of scleractinian corals around Moorea, French Polynesia: patterns across depths and locations. Hydrobiologia., 589: 117-12.

Anderson, K.D and M.S. Pratchett. 2014. Variation in size-frequency distributions of branching corals between a tropical versus sub-tropical reef. Mar. Ecol. Prog. Ser., 502: 117-128.

Andrade, C.A., E.D. Barton, and C.N.K. Mooers. 2003. Evidence for an eastward flow along the Central and South American Caribbean Coast. J. Geophys. Res., 108(C6): 3185. https://doi.org/10.1029/2002JC001549

Ardila, N., G.R. Navas y J. Reyes. 2002. Libro rojo de invertebrados marinos de Colombia. Invemar y Ministerio del Medio Ambiente, Bogotá. 180 p.

Aronson, R.B. and W.F. Precht. 2001. White-band disease and the and the changing face of Caribbean coral reefs. Hydrobiología., 460: 25-38.

Aronson, R.B., A.W. Bruckner, J. Moore, W.F. Precht, and E. Weil. 2008a. IUCN Red List of Threatened Species: Acropora palmata. www.iucnredlist.org. 20/01/2020.

Aronson, R.B., A.W. Bruckner, J. Moore, W.F. Precht y E. Weil. 2008b. IUCN Red List of Threatened Species: Acropora cervicornis. www.iucnredlist.org. 20/01/2020.

Bak, R.P.M. and E.H Meesters. 1998. Coral population structure: the hidden information of colony size-frequency distributions. Mar. Ecol. Prog. Ser., 162: $301-306$.

Bayraktarov, E., V. Pizarro, and C. Wild. 2014a. Spatial and temporal variability of water quality in the coral reefs of Tayrona National Natural Park, Colombian Caribbean. Environ. Monit. Assess., 186(6): 3641-3659.

Bayraktarov, E., M.L. Bastidas-Salamanca, and C. Wild. 2014b. The physical environment in coral reefs of the Tayrona National Natural Park (Colombian Caribbean) in response to seasonal upwelling. Bol. Invest. Mar. Cost., 43(1): 137-157.

Bruckner, A. and R. Bruckner. 1997. Outbreak of coral disease in Puerto Rico. Coral Reefs., 16: 260.

Buddemeier, R., J. Kleypas, and B. Aronson. 2004. Coral reefs and global climate change. Potential contributions of climate change to stresses on Coral Reefs Ecosystems. Pew Center of Global Climate Change, 15(3): 44 p.

Caballero-Aragón, H., S. Perera-Valderrama, N. Rey-Villiers, J. González-Méndez, and M. Armenteros. 2020. Population status of Acropora palmata (Lamarck,1816) in Cuban coral reefs. Reg. Stud. Mar. Sci., 34. https://doi.org/10.1016/j.rsma.2019.101029

Ceccarelli, D., G. Jones, and L. McCook. 2005. Foragers versus farmers. Contrasting effects of two behavioural groups of herbivores on coral reefs. Oecologia., 145: 445-453.

Cendales, M.H., S. Zea y J.M. Díaz. 2002. Geomorfología y unidades ecológicas del complejo de arrecifes de las islas del Rosario e isla Barú (mar Caribe, Colombia). Rev. Acad. Colomb. Cien., 26(101): 497-510.

Crabbe, M.J.C. 2009. Scleractinian coral population size structures and growth rates indicate coral resilience on the fringing reefs of North Jamaica. Mar. Env. Res., 67: 189-198. 
Croquer, A., F. Cavada-Blanco, A.L. Zubillaga, E.A. Agudo-Adriani, and M. Sweet. 2016. Is Acropora palmata recovering? A case study in Los Roques National Park, Venezuela. PeerJ., 4: e1539. https://doi.org/10.7717/peerj.1539

Díaz, J.M., J. Garzón-Ferreira y S. Zea. 1995. Los arrecifes coralinos de la Isla de San Andrés, Colombia: estado actual y perspectivas para su conservación. Acad. Colomb. Cienc. Exac. Fís. Nat., Colec. Jorge Álvarez Lleras, 7: 150 p.

Díaz, J.M,. L.M. Barrios, M. Cendales, J. Garzón-Ferreira, J. Geister, M. López-Victoria, G. Ospina, F. Parra-Velandia, J. Pinzón, B. Vargas-Ángel, F. Zapata y S. Zea. 2000. Áreas coralinas de Colombia. Ser. Publ. Espec. Invemar, (5): 176 p.

Ekebom, J. and A. Enkkilä. 2003. Using aerial photography for identification of marine and coastal habitats under the EU's habitats directive. Aquat. Conser: Mar. Fresh. Eco., 13: 287-304. doi:10.1002/aqc.553

Garzón-Ferreira, J. 1997. Arrecifes coralinos: un tesoro camino a la extinción? Colombia: Ciencia y Tecnología, 15(1): 11-19.

Garzón-Ferreira, J. y M. Cano. 1991. Tipos, distribución, extensión y estado de conservación de los ecosistemas marinos costeros del Parque Nacional Natural Tayrona. Séptimo Concurso Nacional de Ecología. Fondo para la Protección del Medio Ambiente, Bogotá. 82 p.

Garzón-Ferreira, J. and J.M. Díaz. 2003. The Caribbean coral reefs of Colombia. 275-301. En J. Cortés (Ed.), Latin American coral reefs. Amsterdam: Elsevier.

Garzón-Ferreira, J., M. Moreno-Bonilla y J.M. Valderrama. 2004. Condición actual de las formaciones coralinas de Acropora palmata y A. cervicornis en el Parque Nacional Natural Tayrona (Colombia). Bol. Invest. Mar. Cost., 33: 117-136.

Gladfelter, W. 1982. White band disease in Acropora palmata: implications for the structure and growth of shallow reefs. Bull. Mar. Sci., 32: 639-643.

Hall, V.R. and T.P. Hughes. 1996. Reproductive strategies of modular organisms: comparative studies of reef-building corals. Ecology., 77: 950-963.

Hoegh-Guldberg, O. 1999. Climate change, coral bleaching and the future of the world's coral reefs. Mar. Fresh. Res., 50: 839-866.

Hoey, A.S and D.R. Bellwood. 2010. Damselfish territories as a refuge for macroalgae on coral reefs. Coral Reefs, 29: 107-118.

Hughes, T.P. and J.B.C. Jackson. 1985. Population dynamics and life histories of foliaceous corals. Ecol. Monogr., 55: 141-166.

Hughes, T.P and J.H. Connell. 1999. Multiple stressors on coral reefs: a long-term perspective. Limnol. Oceanogr., 44: 932-940.

Hughes, T.P., D. Ayre, and J.H. Connell. 1992. The evolutionary ecology of corals. Trends. Ecol. Evol., 7: 292-295.

Knowlton, N. 2001. The future of coral reefs. Proc. Nat. Acad. Sci., 5419-5428.

Knowlton, N., J. Lang, and B. Keller. 1990. Case study of natural population collapse: Post-hurricane predation on Jamaican staghorn coral. Smithson. Contrib. Mar. Sci. 1-25. https://doi.org/10.5479/si.01960768.31.1

Kohler, K.E. and S.M. Gill. 2006. Coral Point Count with Excel extensions (CPCe): a Visual Basic program for the determination of coral and substrate coverage using random point count methodology. Comp. Geos., 32: 1259-1269.

Kramer, K., D. Williams, M. Miller, C. Begin, J. Fry, and A. Valdivia. 2008. Demographic comparison of the threatened Elkhorn coral, Acropora palmata, in the Caribbean: a case study in successful volunteer partnerships in a regional-scale monitoring program. 765-769. Proc. $11^{\text {th }}$ Int. Coral Reef. Symp., Florida.

Larson, E.A., D.S. Gilliam, M. López Padierna, and B.K. Walker. 2014. Possible recovery of Acropora palmata (Scleractinia: Acroporidae) within the Veracruz Reef System, Gulf of Mexico: a survey of 24 reefs to assess the benthic communities. Rev. Biol. Trop., 62(3): 75-84.

Lewis, J.B. 1989. The ecology of Millepora. A review. Coral Reefs, 8: 99-107.

Linares, C., M.S. Pratchett, and D.J. Coker. 2011. Recolonisation of Acropora hyacinthus following climate-induced coral bleaching on the Great Barrier Reef. Mar. Ecol. Prog. Ser., 438: 97-104.

López-Victoria, M. y J.M. Díaz. 2000. Morfología y estructura de las formaciones coralinas del archipiélago de San Bernardo, Caribe colombiano. Rev. Acad. Colomb. Cienc., 24(91): 219-230.

Meesters, E.H., M. Hilterman, E. Kardinaal, M. Keetman, M. de Vries y R.P.M. Bak. 2001. Colony size-frequency distributions of scleractinian coral populations: spatial and interspecific variation. Mar. Ecol. Prog. Ser., 209: 43-54.

Mejía-Niño, N. y J. Garzón-Ferreira. 2003. Dinámica de las interacciones alga-coral en dos bahías de la región de Santa Marta (Caribe colombiano) con distinto grado de influencia antropogénica. Bol. Invest. Mar. Cost., 32: 243-261.

Muller, E. y R. van Woesik. 2014. Genetic susceptibility, colony size, and water temperature drive white-pox disease on the coral Acropora palmata. PLoS ONE., 9(11): e110759. 
Navas-Camacho, R., D.L. Gil-Agudelo, A. Rodríguez-Ramírez, M.C. Reyes-Nivia y J. Garzón-Ferreira. 2010. Coral diseases and bleaching on Colombian Caribbean coral reefs. Rev Biol Trop., 58(1): 95-106.

Nugues, M., G. Smith, R. van Hooidonk, M. Seabra y R. Bak. 2004. Algal contact as a trigger for coral disease. Ecol. Lett., 7: 919-923.

Ortíz-Royero, J.C. 2007. Huracanes y tormentas tropicales en el mar Caribe colombiano desde 1900. Bol. Cient. CIOH., 25: 54-60.

Patterson, K., J. Porter, K. Ritchie, S. Polson, E. Mueller, E. Peters, D. Santavy, and G. Smith. 2002. The etiology of white pox, a lethal disease of the Caribbean elkhorn coral, Acropora palmata. Ecology, 99(13): 8725-8730.

Porter, J.W., P. Dustan, W.C. Jaap, K.L. Patterson, V. Kosmynin, O.W. Meier, M.E. Patterson, and M. Parsons. 2001. Patterns of spread of coral disease in the Florida Keys. 1-24. In: Porter, J. (Ed.). The ecology and etiology of newly emerging marine diseases. Netherlands: Springer.

Rodríguez-Martínez, R.E., A. Banaszak, and E. Jordan-Dahlgren. 2001. Necrotic patches affect Acropora palmata (Scleractinia: Acroporidae) in the mexican Caribbean. Dis. Aq. Org., 47: 229-234.

Rodríguez-Martínez, R.E., A. Banaszak, M.D. McField, A.U. Beltrán-Torres, and L. Álvarez-Filip. 2014. Assessment of Acropora palmata in the Mesoamerican Reef System. PloS ONE, 9: e96140. https://doi.org/10.1371/journal.pone.0096140

Rodríguez-Ramírez, A., C. Bastidas, S. Rodríguez, Z. Leão, R. Kikuchi, M. Oliveira, D.L. Gil, J. Garzón-Ferreira, M.C. Reyes-Nivia, R. Navas-Camacho, N. Santodomingo, G. Díaz-Pulido, D. Venera-Ponton, L. Flórez-Leiva, A. Rangel-Campo, C. Orozco, J.C. Márquez, S. Zea, M. López-Victoria, J.A. Sánchez, and M.C. Hurtado. 2008. The effects of coral bleaching in the Southern Tropical America: Brazil, Colombia, and Venezuela. 105-114. En: Wilkinson, C and D. Souter (Eds.). Status of Caribbean Coral Reefs after bleaching and hurricanes in 2005. Global Coral Reef Monitoring Network and Reef and Rainforest Research Centre, Townswille. 152 p.

Rogers, C.S and E.M. Muller. 2012. Bleaching, disease and recovery in the threatened scleractinian coral Acropora palmata in St. John, US Virgin Islands: 2003-2010. Coral Reefs., 31: 807-819.

Romero-Rodríguez, D., G. Bernal y S. Zea. 2014. Variables ambientales durante blanqueamiento coralino en el Caribe colombiano. Rev. Acad. Colomb. Cienc., 38(149): 347-355.

Schopmeyer, S. and D. Lirman. 2015. Occupation dynamics and impacts of damselfish territoriality on recovering populations of the threatened staghorn coral, Acropora cervicornis. PLoS ONE., 10(11): e0141302.

Selgrath, J.C., C. Roelfsema, S.E. Gergel y A.C.J. Vincent. 2016. Mapping for coral reef conservation: Comparing the value of participatory and remote sensing approaches. Ecosphere., 7: 1-17. https://doi.org/10.1002/ecs2.1325

Soong, K. 1993. Colony size as a species character in massive reef corals. Coral Reefs., 12: 77-83.

Soong, K. and J.C. Lang. 1992. Reproductive integration in reef corals. Biol. Bull., 183: 418-431.

Sweet, M., J. Bythell, and M. Nugues. 2013. Algae as reservoirs for coral pathogens. PLoS ONE., 8(7): e69717.

Vega-Sequeda, J., A. Rodríguez-Ramírez, M.C. Reyes-Nivia y R. Navas-Camacho. 2008. Formaciones coralinas del área de Santa Marta: estado y patrones de distribución espacial de la comunidad béntica. Bol. Invest. Mar. Cost., 37: 87-105.

Vermeij, M.J.A and R.B. Bak. 2003. Species-specific populations structure of closely related coral morphospecies along a depth gradient (5-60 m) over a Caribbean reef slope. Bull. Mar. Sci., 73: 725-744.

Wirt, K.E., P. Hallock, D. Palandro, and K.L. Daly. 2013. Potential habitat of Acropora spp. on Florida reefs. Ap. Geog., 39: 118-127.

Wirt, K.E., P. Hallock, D. Palandro, K.D. Semon, and K. Lunz. 2015. Potential Habitat of Acropora spp. on Reefs of Florida, Puerto Rico, and the US Virgin Islands. Glob. Ecol. Conserv., 3: 242-255.

Yap, H.T., P.M. Aliño, and E.D. Gómez. 1992. Trends in growth and mortality of three coral species (Anthozoa: Scleractinia), including effects of transplantation. Mar. Ecol. Prog. Ser., 83: 91-101. 


\section{MATERIAL SUPLEMENTARIO}

Material suplementario 1. Áreas estimadas de las formaciones de $A$. palmata y A. cervicornis en el Parque Nacional Natural Tayrona con relación al área reportada por Garzón-Ferreira et al. (2004). Se indica la ubicación geográfica, código de cada formación y tipo de medida para el cálculo de áreas.
Supplementary material 1. Estimated areas of A. palmata and A. cervicornis formations in Tayrona National Natural Park to the area reported by Garzón-Ferreira et al. (2004). The geographical location, code of each formation, and type of measurement are indicated for the calculation of areas.

\begin{tabular}{|c|c|c|c|c|c|c|}
\hline \multicolumn{7}{|c|}{ Acropora palmata } \\
\hline $\begin{array}{l}\text { Ubicación/ } \\
\text { Location }\end{array}$ & Código/Code & Medida/Measure & $\begin{array}{c}\text { Área actual/ } \\
\text { Current area }\left(\mathrm{m}^{2}\right)\end{array}$ & Área $2001\left(m^{2}\right)$ & Latitud/Latitude & Longitud/Lenght \\
\hline $\begin{array}{l}\text { Isla Aguja/ } \\
\text { Aguja Island }\end{array}$ & $1 \mathrm{PN} * *$ & GPS & 314 & & $11^{\circ} 18^{\prime} 39.19^{\prime \prime} \mathrm{N}$ & $74^{\circ} 11^{\prime} 25.587^{\prime \prime} \mathrm{W}$ \\
\hline \multirow{9}{*}{ Chengue } & $2 \mathrm{PN} * *$ & Dron & 1996 & & $11^{\circ} 19^{\prime} 16.032^{\prime \prime} \mathrm{N}$ & $74^{\circ} 7^{\prime} 41.808^{\prime \prime} \mathrm{W}$ \\
\hline & $1 \mathrm{P}$ & GPS & 1372 & 763 & $11^{\circ} 19^{\prime} 43.729^{\prime \prime} \mathrm{N}$ & $74^{\circ} 7^{\prime} 38.078^{\prime \prime} \mathrm{W}$ \\
\hline & $2 \mathrm{P}^{*}$ & & & 708 & & \\
\hline & $3 \mathrm{P}$ & GPS & 1079 & 4352 & $11^{\circ} 19^{\prime} 28.476^{\prime \prime} \mathrm{N}$ & $74^{\circ} 7^{\prime} 40.971^{\prime \prime} \mathrm{W}$ \\
\hline & $4 \mathrm{P}$ & Dron & 19692 & 20423 & $11^{\circ} 19^{\prime} 22.750^{\prime \prime} \mathrm{N}$ & $74^{\circ} 8^{\prime} 5.070^{\prime \prime} \mathrm{W}$ \\
\hline & $5 \mathrm{P}$ & Directo & 238 & 340 & $11^{\circ} 19^{\prime} 37.974^{\prime \prime} \mathrm{N}$ & $74^{\circ} 8^{\prime} 31.191^{\prime \prime} \mathrm{W}$ \\
\hline & $6 \mathrm{P}$ & GPS & 2571 & 2838 & $11^{\circ} 19^{\prime} 7.603^{\prime \prime} \mathrm{N}$ & $74^{\circ} 8^{\prime} 3.437^{\prime \prime} \mathrm{W}$ \\
\hline & $7 \mathrm{P}$ & GPS & 1927 & 3938 & $11^{\circ} 19^{\prime} 4.114^{\prime \prime} \mathrm{N}$ & $74^{\circ} 8^{\prime} 2.189^{\prime \prime} \mathrm{W}$ \\
\hline & $18 \mathrm{P}$ & GPS & 877 & 507 & $11^{\circ} 19^{\prime} 43.489^{\prime \prime} \mathrm{N}$ & $74^{\circ} 7^{\prime} 35.201^{\prime \prime} \mathrm{W}$ \\
\hline \multirow{5}{*}{ Gayraca } & $8 \mathrm{P}$ & GPS & 2207 & 614 & $11^{\circ} 19^{\prime} 40.739^{\prime \prime} \mathrm{N}$ & $74^{\circ} 7^{\prime} 0.046^{\prime \prime} \mathrm{W}$ \\
\hline & 9P & GPS & 4292 & 5187 & $11^{\circ} 19^{\prime} 38.800^{\prime \prime} \mathrm{N}$ & $74^{\circ} 6^{\prime} 53.958^{\prime \prime} \mathrm{W}$ \\
\hline & $10 \mathrm{P} *$ & & & 3304 & & \\
\hline & $11 \mathrm{P}^{*}$ & & & 1493 & & \\
\hline & $12 \mathrm{P}$ & GPS & 4600 & 5762 & $11^{\circ} 19^{\prime} 23.881^{\prime \prime} \mathrm{N}$ & $74^{\circ} 6^{\prime} 45.095^{\prime \prime} \mathrm{W}$ \\
\hline \multirow{10}{*}{ Nenguange } & $3 \mathrm{PN} * *$ & Dron & 6020 & & $11^{\circ} 19^{\prime} 9.301^{\prime \prime} \mathrm{N}$ & $74^{\circ} 4^{\prime} 44.097^{\prime \prime} \mathrm{W}$ \\
\hline & $13 \mathrm{P}$ & GPS & 740 & 1031 & $11^{\circ} 19^{\prime} 12.468^{\prime \prime} \mathrm{N}$ & $74^{\circ} 5^{\prime} 26.016^{\prime \prime} \mathrm{W}$ \\
\hline & $14 \mathrm{P}$ & GPS & 2794 & 4509 & $11^{\circ} 19^{\prime} 13.147^{\prime \prime} \mathrm{N}$ & $74^{\circ} 5^{\prime} 9.399^{\prime \prime} \mathrm{W}$ \\
\hline & $15 \mathrm{P}$ & Dron & 1021 & 1035 & $11^{\circ} 19^{\prime} 3.074^{\prime \prime} \mathrm{N}$ & $74^{\circ} 4^{\prime} 42.447^{\prime \prime} \mathrm{W}$ \\
\hline & $16 \mathrm{P}$ & Dron & 742 & 531 & $11^{\circ} 19^{\prime} 18.775^{\prime \prime} \mathrm{N}$ & $74^{\circ} 4^{\prime} 39.328^{\prime \prime} \mathrm{W}$ \\
\hline & $17 \mathrm{P}$ & Dron & 945 & 722 & $11^{\circ} 19^{\prime} 16.769^{\prime \prime} \mathrm{N}$ & $74^{\circ} 4^{\prime} 39.895^{\prime \prime} \mathrm{W}$ \\
\hline & 19P & Dron & 1909 & 1614 & $11^{\circ} 19^{\prime} 14.971^{\prime \prime} \mathrm{N}$ & $74^{\circ} 4^{\prime} 41.909^{\prime \prime} \mathrm{W}$ \\
\hline & $20 \mathrm{P}$ & Dron & 2095 & 3049 & $11^{\circ} 19^{\prime} 12.607^{\prime \prime} \mathrm{N}$ & $74^{\circ} 4^{\prime} 43.002^{\prime \prime} \mathrm{W}$ \\
\hline & $21 \mathrm{P}$ & GPS & 964 & 803 & $11^{\circ} 19^{\prime} 24.636^{\prime \prime} \mathrm{N}$ & $74^{\circ} 4^{\prime} 41.721^{\prime \prime} \mathrm{W}$ \\
\hline & $22 \mathrm{P} *$ & & & 300 & & \\
\hline
\end{tabular}




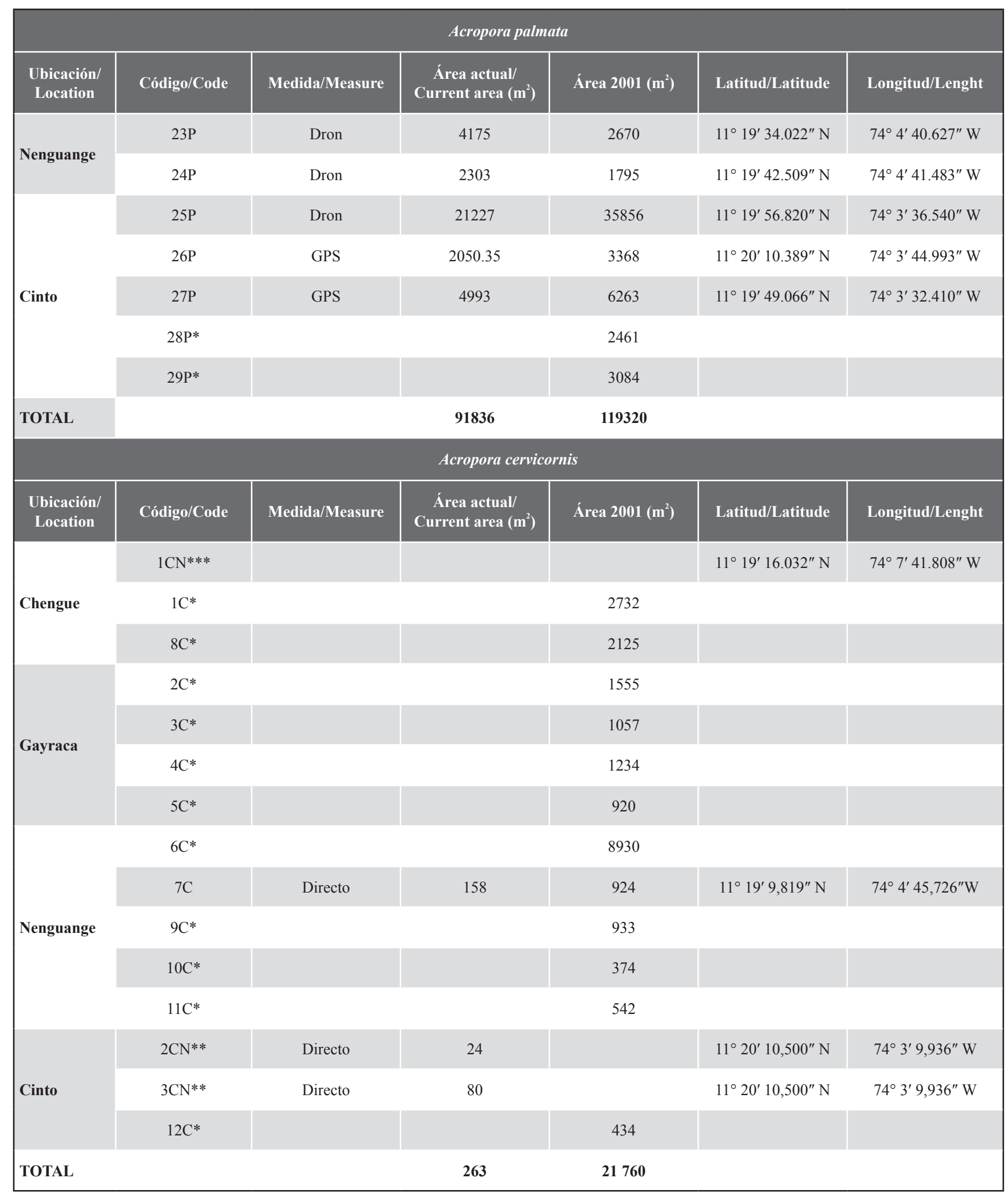

*No fueron encontradas en este estudio. ${ }^{* *}$ Nueva formación encontrada. ${ }^{* * *}$ Colonias aisladas.

*They were not found in this study. **New formation found. ***Isolated colonies. 
Material suplementario 2. Cobertura promedio y desviación estándar (DE) de los componentes principales del sustrato y especies de coral asociadas a las formaciones de Acropora palmata en el Parque Nacional Natural Tayrona e isla Aguja (sector del Torín) (2016-2018). Valores en negrilla resaltan las coberturas más altas.
Supplementary material 2. Average coverage and standard deviation (SD) of the main components of the substrate and coral species associated with the Acropora palmata formations in Tayrona National Natural Park and Aguja Island (Torín sector) (2016-2018). Values in bold highlight higher coverages.

\begin{tabular}{|c|c|c|c|c|c|c|c|c|c|c|}
\hline \multirow[b]{2}{*}{$\begin{array}{l}\text { Categorías principales/ } \\
\text { Main categories }\end{array}$} & \multicolumn{2}{|c|}{ Isla Aguja } & \multicolumn{2}{|c|}{ Chengue } & \multicolumn{2}{|c|}{ Gayraca } & \multicolumn{2}{|c|}{ Nenguange } & \multicolumn{2}{|c|}{ Cinto } \\
\hline & $\begin{array}{l}\text { Promedio/ } \\
\text { Average }\end{array}$ & DE/SD & $\begin{array}{l}\text { Promedio/ } \\
\text { Average }\end{array}$ & DE/SD & $\begin{array}{l}\text { Promedio/ } \\
\text { Average }\end{array}$ & DE/SD & $\begin{array}{l}\text { Promedio/ } \\
\text { Average }\end{array}$ & DE/SD & $\begin{array}{l}\text { Promedio/ } \\
\text { Average }\end{array}$ & $\mathrm{DE} / \mathrm{SD}$ \\
\hline Corales/Corals & 60.50 & 15.84 & 34.8 & 15.8 & 46.23 & 6.01 & 35.9 & 10.72 & 43.90 & 1.16 \\
\hline Gorgonias & 1.00 & 1.41 & 0.2 & 0.4 & 0.03 & 0.07 & 0.0 & 0.16 & 0.40 & 0.53 \\
\hline Esponjas/Sponges & 9.40 & 3.96 & 0.0 & 0.1 & 0.98 & 0.78 & 0.3 & 0.65 & 0.00 & 0.00 \\
\hline Zoantidos & 0.00 & 0.00 & 1.0 & 2.5 & 0.34 & 0.24 & 1.5 & 2.68 & 2.64 & 1.43 \\
\hline Macroalgas/Macroalgae & 21.70 & 8.40 & 47.4 & 6.6 & 49.03 & 5.10 & 58.9 & 7.50 & 45.25 & 4.21 \\
\hline $\begin{array}{l}\text { Arena, pavimento/ } \\
\text { Sand, Pavement }\end{array}$ & 8.10 & 6.08 & 16.6 & 14.4 & 3.38 & 1.00 & 3.3 & 3.41 & 7.67 & 1.41 \\
\hline \multicolumn{11}{|c|}{ Corales/Corals } \\
\hline $\begin{array}{l}\text { Acropora } \\
\text { palmata }\end{array}$ & 41.30 & 7.21 & 15.96 & 8.34 & 29.63 & 11.38 & 16.22 & 9.01 & 18.20 & 15.98 \\
\hline $\begin{array}{l}\text { Agaricia } \\
\text { tenuifolia }\end{array}$ & 0.00 & 0.00 & 0.18 & 0.49 & 1.25 & 2.50 & 0.21 & 0.57 & 0.17 & 0.22 \\
\hline $\begin{array}{l}\text { Colpophyllia } \\
\text { natans }\end{array}$ & 0.00 & 0.00 & 0.09 & 0.26 & 0.00 & 0.00 & 0.66 & 1.50 & 0.09 & 0.11 \\
\hline $\begin{array}{l}\text { Pseudodiploria } \\
\text { clivosa }\end{array}$ & 6.30 & 8.63 & 3.56 & 5.53 & 1.16 & 1.03 & 2.01 & 3.95 & 6.00 & 3.24 \\
\hline $\begin{array}{l}\text { Pseudodiploria } \\
\text { strigosa }\end{array}$ & 5.70 & 4.67 & 1.32 & 1.59 & 4.31 & 3.01 & 1.53 & 1.56 & 3.32 & 2.41 \\
\hline $\begin{array}{l}\text { Diploria } \\
\text { labyrinthiformis }\end{array}$ & 0.00 & 0.00 & 0.00 & 0.0 & 0.25 & 0.50 & 0.01 & 0.03 & 0.00 & 0.00 \\
\hline $\begin{array}{l}\text { Favia } \\
\text { fragum }\end{array}$ & 0.00 & 0.00 & 0.03 & 0.05 & 0.03 & 0.07 & 0.06 & 0.09 & 0.11 & 0.10 \\
\hline $\begin{array}{l}\text { Madracis } \\
\text { decactis }\end{array}$ & 0.00 & 0.00 & 0.00 & 0.00 & 0.00 & 0.00 & 0.07 & 0.22 & 0.00 & 0.00 \\
\hline $\begin{array}{l}\text { Meandrina } \\
\text { meandrites }\end{array}$ & 0.00 & 0.00 & 0.03 & 0.00 & 0.00 & 0.00 & 0.03 & 0.08 & 0.00 & 0.00 \\
\hline $\begin{array}{l}\text { Millepora } \\
\text { alcicornis }\end{array}$ & 0.50 & 0.71 & 0.04 & 0.07 & 0.18 & 0.21 & 0.05 & 0.15 & 0.27 & 0.13 \\
\hline $\begin{array}{l}\text { Millepora } \\
\text { complanata }\end{array}$ & 2.10 & 2.97 & 4.64 & 6.72 & 3.48 & 2.06 & 7.97 & 7.09 & 4.67 & 3.29 \\
\hline $\begin{array}{l}\text { Millepora } \\
\text { squarrosa }\end{array}$ & 0.40 & 0.57 & 0.91 & 1.52 & 2.25 & 4.37 & 3.08 & 3.70 & 1.42 & 1.00 \\
\hline
\end{tabular}




\begin{tabular}{|c|c|c|c|c|c|c|c|c|c|c|}
\hline \multirow[b]{2}{*}{$\begin{array}{l}\text { Categorías principales/ } \\
\text { Main categories }\end{array}$} & \multicolumn{2}{|c|}{ Isla Aguja } & \multicolumn{2}{|c|}{ Chengue } & \multicolumn{2}{|c|}{ Gayraca } & \multicolumn{2}{|c|}{ Nenguange } & \multicolumn{2}{|c|}{ Cinto } \\
\hline & $\begin{array}{l}\text { Promedio/ } \\
\text { Average }\end{array}$ & DE/SD & $\begin{array}{l}\text { Promedio/ } \\
\text { Average }\end{array}$ & DE/SD & $\begin{array}{l}\text { Promedio/ } \\
\text { Average }\end{array}$ & DE/SD & $\begin{array}{l}\text { Promedio/ } \\
\text { Average }\end{array}$ & DE/SD & $\begin{array}{l}\text { Promedio/ } \\
\text { Average }\end{array}$ & DE/SD \\
\hline $\begin{array}{l}\text { Orbicella } \\
\text { annularis }\end{array}$ & 0.20 & 0.28 & 1.78 & 3.18 & 0.23 & 0.47 & 0.01 & 0.05 & 1.61 & 1.29 \\
\hline $\begin{array}{l}\text { Montastraea } \\
\text { cavernosa }\end{array}$ & 1.80 & 2.55 & 0.38 & 0.90 & 0.02 & 0.03 & 0.01 & 0.05 & 0.29 & 0.44 \\
\hline $\begin{array}{l}\text { Orbicella } \\
\text { faveolata }\end{array}$ & 0.70 & 0.99 & 0.03 & 0.05 & 0.07 & 0.13 & 0.12 & 0.39 & 0.57 & 0.98 \\
\hline $\begin{array}{l}\text { Porites } \\
\text { astreoides }\end{array}$ & 0.30 & 0.42 & 0.43 & 0.44 & 0.27 & 0.37 & 0.49 & 0.99 & 0.11 & 0.10 \\
\hline $\begin{array}{l}\text { Porites } \\
\text { porites }\end{array}$ & 0.50 & 0.71 & 0.25 & 0.59 & 0.20 & 0.28 & 0.09 & 0.19 & 0.00 & 0.00 \\
\hline $\begin{array}{l}\text { Siderastrea } \\
\text { radians }\end{array}$ & 0.00 & 0.00 & 0.01 & 0.04 & 0.00 & 0.00 & 0.52 & 1.72 & 0.02 & 0.04 \\
\hline $\begin{array}{l}\text { Siderastrea } \\
\text { siderea }\end{array}$ & 0.60 & 0.57 & 5.02 & 6.79 & 2.85 & 2.65 & 2.83 & 3.37 & 2.51 & 2.21 \\
\hline
\end{tabular}

